\title{
Production and utilization of ensiled forages by beef cattle, dairy cows, pregnant ewes and finishing lambs - A review
}

\author{
Tim.W.J. Keady ${ }^{1}$, James.P. Hanrahan ${ }^{1}$, Christina.L. Marley ${ }^{2}$ and Nigel.D. Scollan ${ }^{2}$ \\ ${ }^{1}$ Animal and Grassland Research and Innovation Centre, Teagasc, Athenry, Co. Galway, Ireland \\ ${ }^{2}$ Institute of Biological Environmental and Rural Sciences, Aberystwyth University, Gogerddan, \\ Aberystwyth, Wales, UK, SY23 3EB \\ e-mail: nigel.scollan@aber.ac.uk
}

\begin{abstract}
This paper reviews the production of, and factors affecting the performance of dairy cows, beef cattle and sheep offered silage based diets in Ireland and UK. Digestibility is the most important factor influencing the feed value of grass silage and consequently animal performance. Each $10 \mathrm{~g} \mathrm{~kg}^{-1}$ increase in digestive organic matter in the dry matter (DOMD) increases milk yield of dairy cows by $0.33 \mathrm{~kg} \mathrm{~d}^{-1}$, carcass gain of beef cattle by $23.8 \mathrm{~g} \mathrm{~d}^{-1}$, carcass gain of finishing lambs by $9.3 \mathrm{~g} \mathrm{~d}^{-1}$, lamb birth weight by $52.3 \mathrm{~g}$ and ewe weight post lambing by $1.3 \mathrm{~kg}$, respectively. Factors influencing feed value of grass silage are discussed including harvest date, wilting, fertilizer management, chop length and use of additives at ensiling. Maize silage increases the performance of cattle and sheep whilst whole crop wheat silage has no beneficial effect. Advances in silage technology, has enabled the ensiling high protein forages, such as red clover, lucerne and kale.
\end{abstract}

Key words: milk yield, carcass gain, grass silage, maize silage, whole crop wheat silage, red clover, lucerne, kale

\section{Introduction}

Grass silage is the basic component of beef, milk and sheep production systems, in Ireland, UK, Scandinavia, many other parts of Europe, New Zealand, Australia and North America, during the winter feeding period. Levels of animal performance achieved from grass silage are variable reflecting its feed value. Grass silage feed value is a reflection of the stage of maturity of herbage at ensiling, management at ensiling and the fermentation process all of which impact on digestibility (the major factor influencing feed value) and subsequently animal performance. High feed-value grass silage can deliver high levels of animal performance. However in practice the preparation of high feed-value grass silage is often difficult due to a wide variety of factors, including prevailing weather conditions.

Given the increase in costs of concentrate inputs and availability and costs of major protein sources, such as soyabean meal, there is much renewed emphasis on maximising production from both grazed and ensiled forages. As silages differ in feed value cattle and sheep are normally supplemented with concentrates to achieve commercially optimum production levels. In recent years other ensiled forages, including maize (Zea mays), whole crop wheat (Triticum aestivum), kale (Brassica oleracea) and legumes such as red clover (Trifolium pratense) and lucerne (Medicago sativa), have partially replaced grass silage in the diet of growing and lactating ruminants. The objective in this paper is to investigate factors influencing the feed value of grass silage and effects on animal performance. The effects of including maize and whole crop wheat silages in grass silage-based diets on the performance of lactating dairy cows, finishing beef cattle, pregnant ewes and finishing lambs is discussed along with recent progress in the ensiling of high protein forage legumes. Whilst much of the literature cited in this paper is from Ireland and the UK, it is relevant to most regions with temperate climate, and the principles apply to most silage production and its utilization world wide. 


\section{Effects of ensiling on forage intake}

It is often assumed that ensiling results in a reduction in forage intake and animal performance, as in practice cattle and sheep grazing outdoors have higher intakes than those indoors receiving silage. However this is not a valid comparison as the animals are usually at different stages in their production cycle, grazing animals can select the forage, whilst those offered silage (particularly if precision chopped) cannot select, and other management, animals and feed factors differ. Keady and Murphy (1993) reviewed data from 75 and 14 comparisons undertaken with sheep and beef cattle and showed a mean reduction in silage dry matter (DM) intake of $37 \%$ and $6 \%$ relative to the parent herbage respectively. However, the fermentation characteristics of the silages offered in these studies differed dramatically. Silage intake characteristics are different for the ovine and bovine (Cushnahan et al. 1994). Keady and Murphy (1993) reviewed 7 comparisons of the effects of ensiling on forage intake of heifers and sheep and reported that whilst offered the same forages, ensiling reduced forage intake by sheep whilst having no effect when offered to heifers. More recently Keady et al. (1995) and Keady and Murphy (1998) reported that when silage is produced using good ensiling management then ensiling per se had no effect on forage intake (Table 1), but reduced animal performance due to changes in the nitrogenous components and reduced energy value of volatile fatty acids as energy sources for the rumen microflora.

Table 1. The effects of ensiling on herbage composition and animal performance

\begin{tabular}{ccc}
\hline & \multicolumn{2}{c}{ Treatment } \\
\hline Forage composition & Fresh grass & Silage (70 days ensiled) \\
Dry matter $\left(\mathrm{g} \mathrm{kg}^{-1}\right)$ & 172 & 184 \\
$\mathrm{pH}$ & 6.41 & 3.89 \\
Crude protein $\left(\mathrm{g}(\mathrm{kg} \mathrm{DM})^{-1}\right)$ & 176 & 173 \\
Water soluble carbohydrate $\left(\mathrm{g}\left(\mathrm{kg} \mathrm{DM}^{-1}\right)\right.$ & 130 \\
Dry matter digestibility $\left(\mathrm{g}\left(\mathrm{kg} \mathrm{DM}^{-1}\right)\right.$ & 739 & 752 \\
Animal performance & & 13.0 \\
Forage dry matter intake $\left(\mathrm{kg} \mathrm{d}^{-1}\right)$ & 13.6 & 12.3 \\
Milk yield $\left(\mathrm{kg} \mathrm{d}^{-1}\right)$ & 14.1 & 0.84 \\
Fat plus protein yield $\left(\mathrm{kg} \mathrm{d}^{-1}\right)$ & 0.98 & \\
\hline
\end{tabular}

Keady et al. 1995, Keady and Murphy 1998

During the ensiling process, major changes occur in the chemical composition of herbage. Two major changes are the conversion of water-soluble carbohydrate (WSC) primarily to lactic and volatile fatty acids, and secondly an increase in the rapidly soluble component of crude protein due to proteolysis and deamination processes (McDonald et al. 1991). Supplementation of silage with sucrose to replenish carbohydrate lost during the ensiling process doesn't compensate for the reduced animal performance due to ensiling per se (Keady and Murphy 1998). However, supplementation with fishmeal, a known source of undegraded dietary protein, increased animal performance probably due to improved efficiency of rumen microbial protein synthesis as protein in silage is extensively degraded in the rumen (Keady and Murphy 1998).

\section{Grass silage feed value}

To obtain the optimum level of performance from finishing beef cattle and lactating dairy cows, finishing lambs and pregnant ewes grass silages are normally supplemented with concentrates. The level of concentrate supplementation is dependent on the feed value of the silage and the stage of the production cycle of the animals being offered the silage. The feed value of grass silage is a combination of its intake potential and nutritive value, which is determined primarily by digestibility. 


\section{Silage digestibility}

Digestibility is the most important factor influencing feed value of grass silage and, consequently, the performance of animals offered diets based on grass silage (Keady 2000). Data from studies, undertaken using lactating dairy cows, finishing beef cattle, pregnant ewes and finishing lambs that were offered grass silages differing in digestibility, were collated to evaluate the effects of increasing silage digestibility on animal performance. Where not available, the digestible organic matter in the dry matter (DOMD, D-value) of the grass silage was determined using the equation of Keady et al. (2001):

$\mathrm{DMD}=49.1+0.988 \mathrm{DOMD}, \mathrm{R}^{2}=0.95$

The available data were categorised according to the source and least squares procedures were used to fit a model with source as a fixed effect and the proportion of forage in the diet as a covariate; the linearity of the effect of forage proportion was tested in all cases by fitting a quadratic term but this was not significant in any case except for live-weight gain of lambs. The $\mathrm{R}^{2}$ value for the variation attributable to regression relative to the variation that remained after fitting source was calculated as a guide to the explanatory value of the regressor.

There is a substantial body of evidence to indicate that increasing silage digestibility increases silage DM intake (DMI) and milk yield. The effects of digestibility on food intake and performance of lactating dairy cows from 23 comparisons are presented in Table 2. The mean responses to an increase of $10 \mathrm{~g} \mathrm{~kg}^{-1}$ in DOMD were: increased silage DMI $0.22 \pm 0.071 \mathrm{~kg} \mathrm{~d}^{-1}$, milk yield $0.33 \pm 0.041 \mathrm{~kg} \mathrm{~d}^{-1}$, protein concentration $0.087 \pm 0.0292 \mathrm{~g} \mathrm{~kg}^{-1}$ and yield of fat plus protein $0.026 \pm 0.0027 \mathrm{~kg} \mathrm{~d}^{-1}$, and a reduction in fat concentration $-0.019 \pm 0.0548 \mathrm{~g} \mathrm{~kg}^{-1}$. Whilst the mean response in milk yield was $0.33 \mathrm{~kg}$ for each $10 \mathrm{~g} \mathrm{~kg}^{-1}$ increase in silage DOMD the response varied from -0.26 to $0.85 \mathrm{~kg}$. The variation in milk yield response to a change in silage digestibility may be due to many factors including cow genotype, forage:concentrate $(\mathrm{F}: \mathrm{C})$ ratio. When the responses in Table 2 were analysed with a model that included effects for data source and the proportion of forage in the diet, the regression on forage proportion was not significant for any performance variable except protein concentration $(p<0.03)$ and approached formal significance for milk yield $\left(\mathrm{R}^{2}=0.23, p<0.09\right)$. The estimates of the response in silage $\mathrm{DMI}$, the yields of milk and of fat plus protein, and the concentrations of fat and protein are displayed in Table 3 for $F: C$ ratios of 80:20, 60:40, and 40:60. The milk yield response per $10 \mathrm{~g} \mathrm{~kg}^{-1}$ increase in silage DOMD was 0.58, 0.37 and $0.16 \mathrm{~kg} \mathrm{~d}^{-1}$ when the $\mathrm{F}: \mathrm{C}$ ratio was $80: 20,60: 40$ and $40: 60$ respectively. These estimates show that whilst the response declined as proportion of concentrate increased there was still a significant response in terms of fat plus protein yield and protein concentration when high levels of concentrate (60\% of DM intake) were offered.

The effects of silage digestibility on food intake and performance of finishing beef cattle from 34 comparisons are summarised in Table 4. The mean responses to each $10 \mathrm{~g} \mathrm{~kg}^{-1}$ increase in silage DOMD were: increased silage DMI $0.07 \pm 0.007 \mathrm{~kg} \mathrm{~d}^{-1}$, live-weight gain $30.5 \pm 2.66 \mathrm{~g} \mathrm{~d}^{-1}$ and carcass gain $22.8 \pm 2.00 \mathrm{~kg} \mathrm{~d}^{-1}$. Whilst the mean response in carcass gain was $22.8 \mathrm{~kg} \mathrm{~d}^{-1}$ for each $10 \mathrm{~kg} \mathrm{~d}^{-1}$ increase in silage DOMD the response estimates varied significantly with $\mathrm{F}: \mathrm{C}$ ratio $\left(p<0.01, \mathrm{R}^{2}=0.70\right)$; the estimates for $\mathrm{F}: \mathrm{C}$ ratios from 100:0 down to 40:60 are given in Table 3 for silage DMI, live-weight gain and carcass gain The carcass gain response per $10 \mathrm{~g} \mathrm{~kg}^{-1}$ increase in silage DOMD was 35, 26, 17 and 8 when the F:C ratio was 100:0, 80:20, 60:40, and 40:60, respectively. Whilst the response to increased silage DOMD declined as concentrate proportion in the diet increased, a significant response to silage DOMD was still evident when concentrate accounted for $60 \%$ of the total DMI. Steen et al. (2002) and Keady and Kilpatrick (2006) concluded that high feed-value grass silage can sustain high levels of beef cattle per-

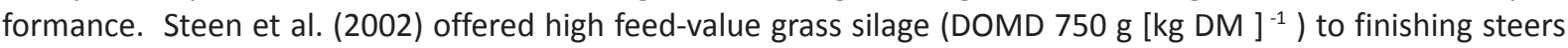
and reported no increase in carcass gain $\left(0.78 \mathrm{~kg} \mathrm{~d}^{-1}\right)$ when concentrate accounted for more than $40 \%$ of the diet. Keady and Kilpatrick (2006) showed that bulls offered high feed-value grass silage (DOMD $775 \mathrm{~g}[\mathrm{~kg} \mathrm{DM}]^{-1}$ ) as $50 \%$ of the diet sustained the same live-weight gain $\left(1.6 \mathrm{~kg} \mathrm{~d}^{-1}\right)$ as bulls offered concentrate for ad libitum consumption. 


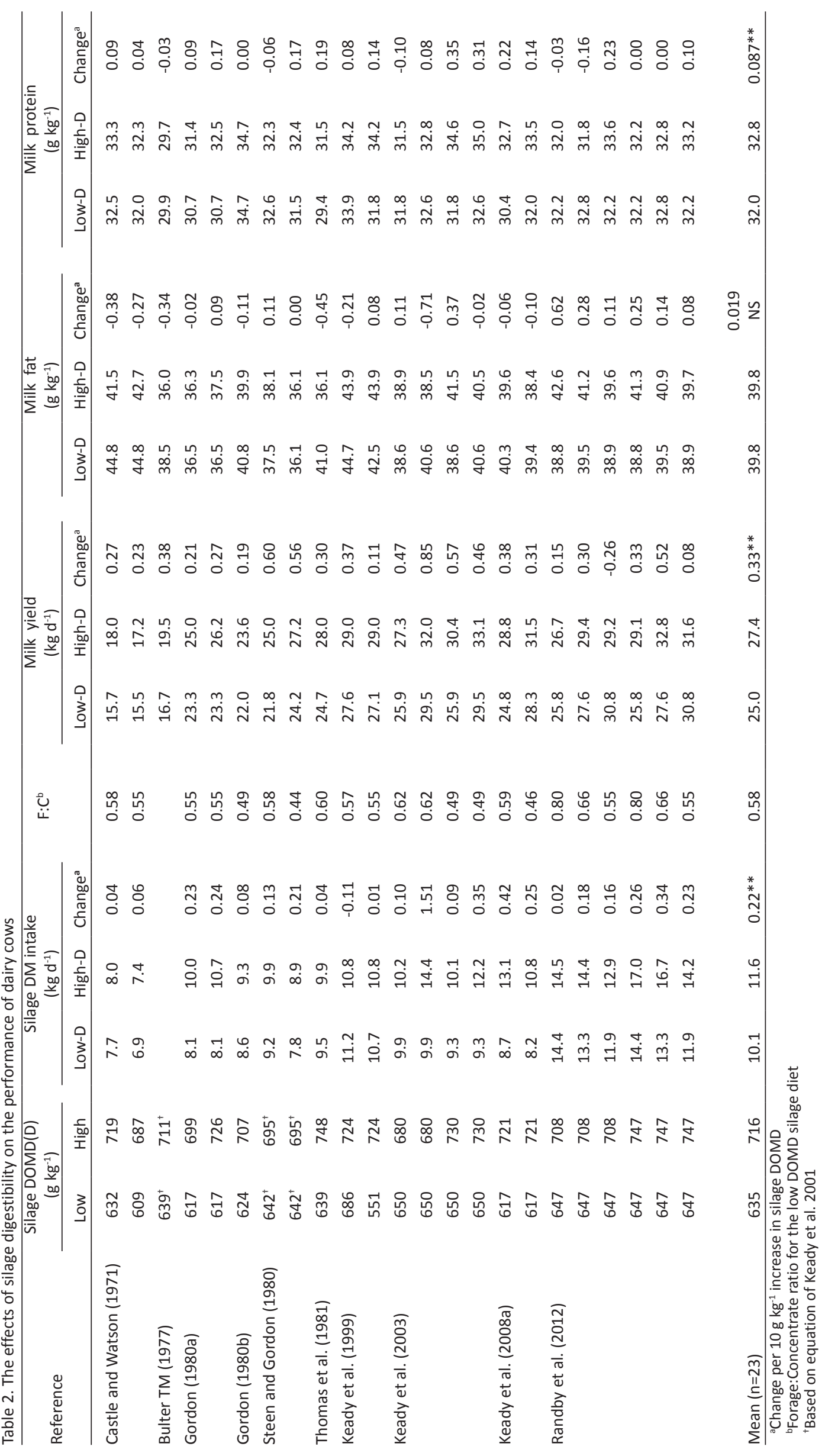


T.W.J. Keady et al. (2013) 22: 70-92

Table 3. Responses in silage intake and performance of lactating dairy cows, and finishing beef cattle and lambs to a change of $10 \mathrm{~g}$ $\mathrm{kg}^{-1}$ in grass silage DOMD at various forage:concentrate ratios

\begin{tabular}{|c|c|c|c|c|c|}
\hline \multirow{2}{*}{$\begin{array}{l}\text { Animal } \\
\text { type }\end{array}$} & \multirow[t]{2}{*}{ Performance trait } & \multicolumn{3}{|c|}{ Forage: concentrate ratio } & \multirow[b]{2}{*}{$40: 60$} \\
\hline & & $100: 0$ & $80: 20$ & $60: 40$ & \\
\hline \multirow[t]{5}{*}{ Dairy } & Milk yield $\left(\mathrm{kg} \mathrm{d}^{-1}\right)$ & - & $0.58 \pm 0.144$ & $0.37 \pm 0.050$ & $0.16 \pm 0.100$ \\
\hline & Fat $\left(\mathrm{g} \mathrm{kg}^{-1}\right)$ & - & $-0.01 \pm 0.220$ & $-0.07 \pm 0.076$ & $-0.13 \pm 0.152$ \\
\hline & Protein $\left(\mathrm{g} \mathrm{kg}^{-1}\right)$ & - & $0.14 \pm 0.093$ & $0.06 \pm 0.032$ & $0.26 \pm 0.065$ \\
\hline & Fat + Protein yield $\left(\mathrm{kg} \mathrm{d}^{-1}\right)$ & - & $0.037 \pm 0.0101$ & $\mathbf{0 . 0 2 6} \pm 0.0035$ & $0.015 \pm 0.0070$ \\
\hline & Silage DM intake $\left(\mathrm{kg} \mathrm{d}^{-1}\right)$ & - & $0.33 \pm 0.277$ & $0.20^{\ddagger} \pm 0.096$ & $0.07 \pm 0.192$ \\
\hline \multirow[t]{3}{*}{ Beef } & Live-weight gain $\left(\mathrm{kg} \mathrm{d}^{-1}\right)$ & $47 \pm 5.4$ & $30 \pm 3.3$ & $12 \pm 4.0$ & $-5 \pm 6.7$ \\
\hline & Carcass gain $\left(\mathrm{g} \mathrm{d}^{-1}\right)$ & $35 \pm 4.0$ & $26 \pm 2.5$ & $17 \pm 2.9$ & $8 \pm 4.8$ \\
\hline & DM intake $\left(\mathrm{kg} \mathrm{d}^{-1}\right)$ & $0.12 \pm 0.019$ & $0.09 \pm 0.006$ & $0.07 \pm 0.014$ & $0.04 \pm 0.024$ \\
\hline \multirow[t]{2}{*}{ Lamb } & Carcass gain $\left(\mathrm{g} \mathrm{d}^{-1}\right)$ & $16 \pm 2.3$ & $13 \pm 1.3$ & $9 \pm 0.9$ & $6 \pm 1.5$ \\
\hline & DM intake $\left(\mathrm{kg} \mathrm{d}^{-1}\right)$ & $0.08 \pm 0.007$ & $0.07 \pm 0.004$ & $0.05 \pm 0.003^{\ddagger}$ & $0.03 \pm 0.005$ \\
\hline
\end{tabular}

Responses in bold are significantly different from zero $(p<0.05)$

${ }^{\ddagger} \mathrm{P}+0.057$

The effects of silage digestibility on ewe weight at lambing and lamb birth weight, from 9 comparisons, are presented in Table 5. The mean response to each $10 \mathrm{~g} \mathrm{~kg}^{-1}$ increase in silage DOMD was an increase in ewe weight post lambing of $1.3 \pm 0.08 \mathrm{~kg}$ and an extra $52.3 \pm 11.41 \mathrm{~g}$ in lamb birth weight. Whilst the mean response in lamb birth weight per $10 \mathrm{~g} \mathrm{~kg}^{-1}$ increase in silage DOMD was $52.3 \mathrm{~g}$ it varied from -20 to $101.8 \mathrm{~g} \mathrm{~d}^{-1}$. When the 9 comparisons in Table 5 were analysed for the effect of concentrate input in late pregnancy (as a proxy for the proportion of forage in the diet) there was no evidence of any association between silage D-value and forage:concentrate ratio of the diet. Lamb birth weight is positively related to weaning weight and an increase of $1 \mathrm{~kg}$ in lamb birth weight results in an increase of $3.2 \mathrm{~kg}$ in weaning weight (based on Keady et al. 2007 and Keady and Hanrahan 2009b and c).

The effects of silage digestibility on food intake and performance of finishing lambs from 10 comparisons are presented in Table 6. The mean responses in silage DMI, live-weight gain and carcass gain to each $10 \mathrm{~g} \mathrm{~kg}^{-1}$ increase in silage DOMD were $0.05 \pm 0.006 \mathrm{~kg} \mathrm{~d}^{-1}, 14.4 \pm 2.74 \mathrm{~g} \mathrm{~d}^{-1}$ and $9.3 \pm 1.32 \mathrm{~g} \mathrm{~d}^{-1}$, respectively. The response to silage DOMD varied significantly with F:C ratio $\left(R^{2}=0.61\right.$ : $p<0.03$ for carcass gain). The estimates of response as a function of $\mathrm{F}: \mathrm{C}$ ratio are given in Table 3 and show that a significant response was observed for $\mathrm{F}: \mathrm{C}$ ratios as low as 0.4 . The carcass gain responses per $10 \mathrm{~g} \mathrm{~kg}^{-1}$ increase in silage DOMD were 16, 13, 9 and $6 \mathrm{~g} \mathrm{~d}^{-1}$ for F:C ratios of 100:0, $80: 20,60: 40$ and, 40:60, respectively.

In summary, silage digestibility is positively correlated with carcass gain of beef cattle and finishing lambs, milk yield and composition of dairy cows, and lamb birth weight and ewe weight post lambing.

\section{Effects of silage digestibility on concentrate sparing effect}

The level of concentrate supplementation required for silage-based diets to ensure target performance levels is dependent on the feed value of the silage and the stage of the production cycle of the animals being offered the silage. When concentrate price is high relative to product price (milk or meat) one of the potential benefits of increasing silage digestibility is the opportunity to maintain animal performance whilst reducing concentrate input.

As the evidence indicates that increasing silage digestibility increases silage intake and animal performance the latter can be maintained by increasing silage digestibility whilst reducing concentrate feed levels. Animal performance data from the 23, 34, 9 and 10 comparisons summarized in Tables 2-6 were analysed with a linear model having source as a fixed effect and silage DOMD and concentrate intake as covariates; the non-linearity of the covariate effects was tested in all cases.

The resulting regression equations describing the effects of silage digestibility and concentrate feed level on the performance of lactating dairy cows, finishing beef cattle, finishing lambs and pregnant ewes are presented in Table 7. There was an interaction between the linear responses of beef cattle to changes in DOMD and concentrate intake as well as a significant quadratic response to concentrate intake. There was no interaction $(p>0.05)$ between silage DOMD and concentrate feed level, or any quadratic effects, for the response in the performance of lactating dairy cows, finishing lambs or pregnant ewes. Each increase of 5 percentage units in silage DOMD enabled the yields of milk and of fat plus protein from dairy cows, carcass gain by finishing lambs and lamb birth weight to be maintained whilst concentrate feed level (DM basis) was reduced by $2.35 \mathrm{~kg} \mathrm{~d}^{-1}, 2.80 \mathrm{~kg} \mathrm{~d}^{-1}, 0.30 \mathrm{~kg}^{2}$ $\mathrm{d}^{-1}$ and $19.2 \mathrm{~kg}$ during late pregnancy, respectively. 


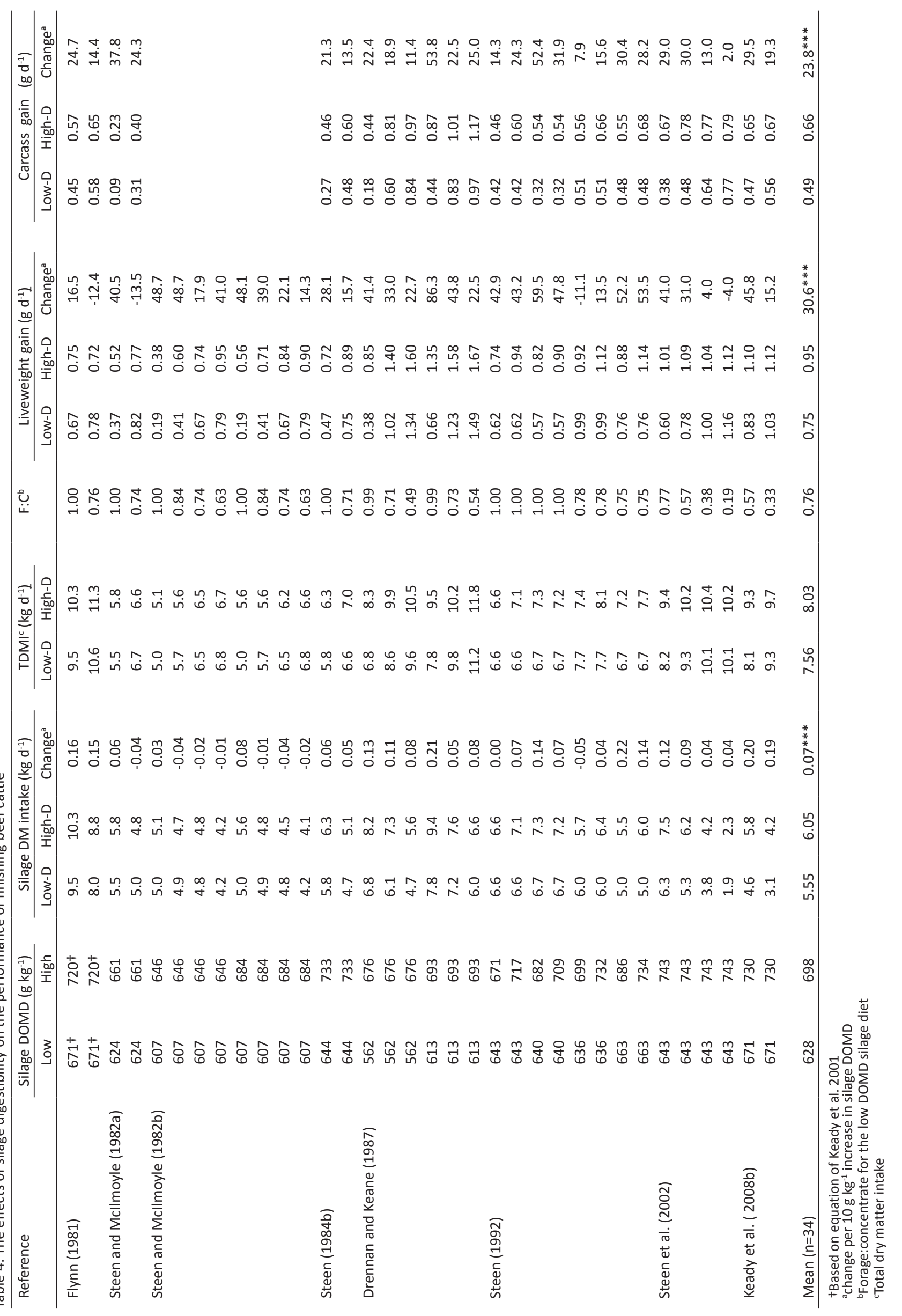




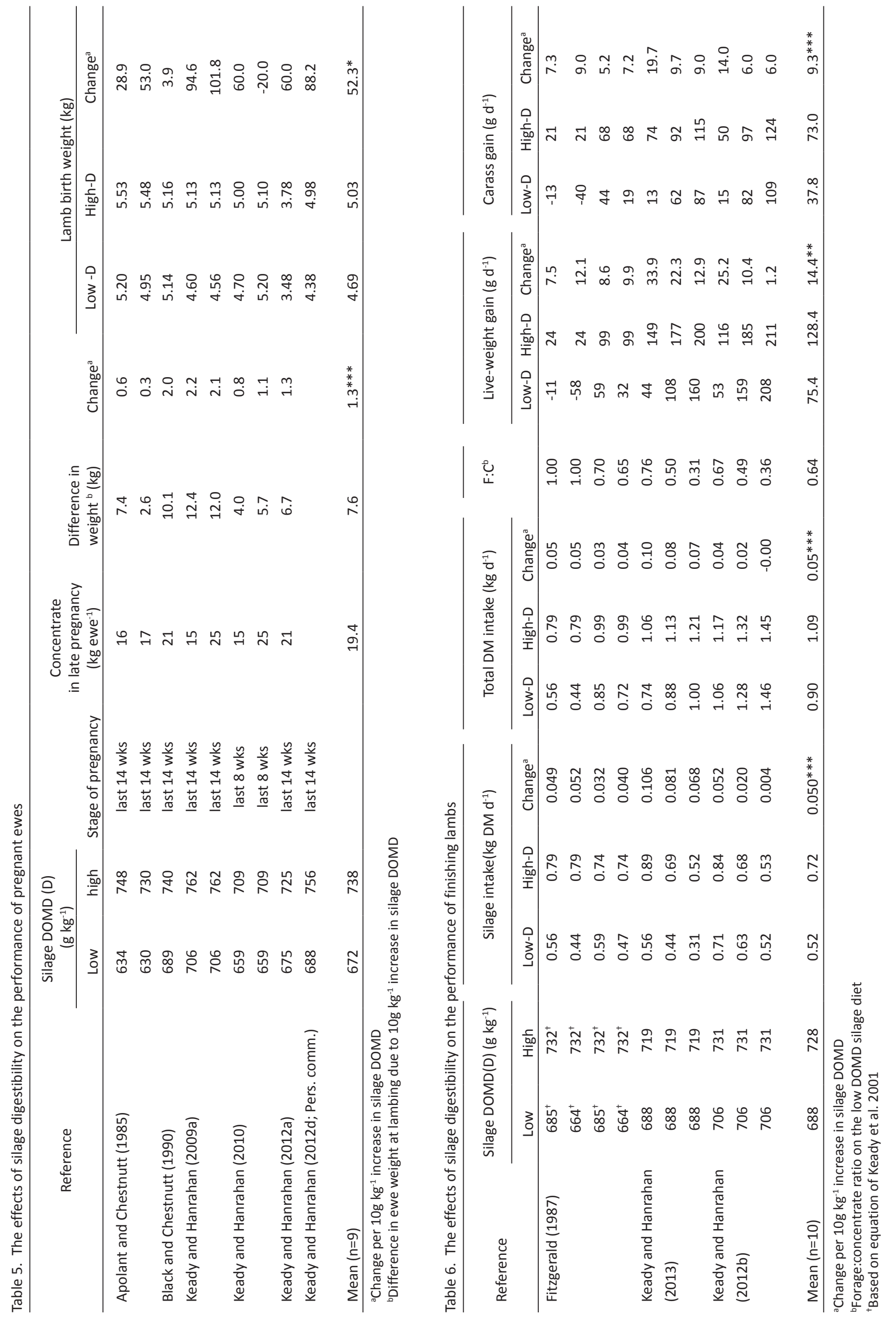


Table 7. Regression equations for the relationship of animal performance with silage digestibility and concentrate feed level

\begin{tabular}{|c|c|c|c|c|c|c|c|c|}
\hline \multirow{2}{*}{$\begin{array}{l}\text { Animal } \\
\text { type }\end{array}$} & \multirow{2}{*}{$\begin{array}{l}\text { Performance } \\
\text { trait }\end{array}$} & \multirow{2}{*}{ Constant } & \multicolumn{4}{|c|}{ Regresssion coefficient (s.e.) for } & \multirow[t]{2}{*}{$\mathrm{R}^{2}$} & \multirow{2}{*}{ Sig? } \\
\hline & & & $\mathrm{DOMD}^{+}$ & Conc $^{\S}$ & D-value*Conc & Conc $^{2}$ & & \\
\hline \multirow[t]{2}{*}{$\begin{array}{l}\text { Dairy } \\
\text { cows }\end{array}$} & $\begin{array}{l}\text { Milk yield } \\
\left(\mathrm{kg} \mathrm{d}^{-1}\right)\end{array}$ & 4.85 & $+0.260(0.0462)$ & $+0.554(0.1265)$ & & & 0.61 & $* * *$ \\
\hline & $\begin{array}{l}\text { Fat \& Protein } \\
\left(\mathrm{kg} \mathrm{d}^{-1}\right)\end{array}$ & -0.034 & $+0.023(0.0036)$ & $+0.041(0.0098)$ & & & 0.64 & $* * *$ \\
\hline $\begin{array}{l}\text { Beef } \\
\text { cattle }\end{array}$ & $\begin{array}{l}\text { Carcass gain } \\
\left(\mathrm{kg} \mathrm{d}^{-1}\right)\end{array}$ & -1.90 & $+0.033(0.0037)$ & $+0.333(0.0661)$ & $-0.0036(0.00100)$ & $-0.0038(0.00199)$ & 0.75 & $* * *$ \\
\hline $\begin{array}{l}\text { Finishing } \\
\text { lambs }\end{array}$ & $\begin{array}{l}\text { Carcass gain } \\
\left(\mathrm{g} \mathrm{d}^{-1}\right)\end{array}$ & -632 & $+8.6(1.21)$ & $+142.4(13.60)$ & & & 0.91 & $* * *$ \\
\hline $\begin{array}{l}\text { Pregnant } \\
\text { ewes }\end{array}$ & Lamb BW (kg) & 0.73 & $+0.050(0.0115)$ & $+0.013(0.0120)$ & & & 0.67 & $* * *$ \\
\hline
\end{tabular}

${ }^{+}$In units of $10 \mathrm{~g} \mathrm{~kg}^{-1} ;{ }^{\S} \mathrm{C}$ oncentrate dry matter $\left(\mathrm{kg} \mathrm{d}^{-1}\right)$

"Significance of the regression equation.

An analysis of the relationship between the delay in harvest date and the corresponding change in digestibility was undertaken using data from studies that involved at least 3 harvest dates (Gordon 1980a, Steen 1984b, Drennan and Keane 1987, and Keady et al. 2000). The model used had source as a fixed effect and number of days as a covariate. This analysis yielded a significant linear relationship between the number of days by which harvest date was delayed and the corresponding change in D-value $\left(\mathrm{g} \mathrm{kg}^{-1}\right)$. The regression coefficient was $4.8 \pm 0.68 \mathrm{~g} \mathrm{~kg}^{-1}$ per 1 day delay $\left(p<0.001, R^{2} 0.86\right)$. Thus, silage digestibility declines, on average, by 3.3 percentage units for each 1 week delay in harvest date. Consequently, for each 1 week delay in harvest an extra $1.55 \mathrm{~kg} \mathrm{~d}^{-1}, 0.20 \mathrm{~kg} \mathrm{~d}^{-1}$ and $12.7 \mathrm{~kg}$ (in late pregnancy) of concentrate (DM) is required to maintain milk yield of dairy cows, carcass gain of lambs and lamb birth weight. For finishing beef cattle offered silage with a DOMD of 670 or $710 \mathrm{~g} \mathrm{~kg}^{-1}$ and a daily concentrate supplement of $4 \mathrm{~kg} \mathrm{DM}$, each 1 week delay in harvest date requires an additional concentrate DM input of 0.99 and $1.30 \mathrm{~kg} \mathrm{~d}^{-1}$ to maintain carcass gain (Table 8 ).

Table 8. Effects of a change $\left( \pm 50 \mathrm{~g} \mathrm{~kg}^{-1}\right)$ in silage DOMD on the concentrate sparing effect with beef cattle offered silages differing in DOMD and supplemented with different levels of concentrate

\begin{tabular}{llccc} 
& & \multicolumn{3}{c}{ Concentrate DM $\left(\mathrm{kg} \mathrm{day}^{-1}\right)$} \\
\cline { 3 - 5 } DOMD & (DMD) & 2 & 4 & 6 \\
\hline 670 & $(711)$ & 1.67 & 1.50 & 1.21 \\
690 & $(731)$ & 1.85 & 1.70 & 1.44 \\
710 & $(751)$ & 2.07 & 1.97 & 1.77 \\
730 & $(771)$ & 2.35 & 2.34 & 2.32 \\
\hline
\end{tabular}

\section{Major factors affecting digestibility of grass silage Harvest date}

Most of the factors that effect silage digestibility can be controlled by the producer. Harvest date is the most important factor affecting silage digestibility. Silage digestibility declines as harvest date is delayed. An analysis of the relationship between the delay in harvest date and the corresponding change in digestibility was undertaken using data from studies that involved at least 3 harvest dates (Gordon 1980a, Steen 1984, Drennan and Keane 1987, Steen et a.l 1992 and Keady et al. 2000). The model used had source as a fixed effect and number of days as a covariate. This analysis yielded a significant linear relationship between the number of days by which harvest date was delayed and the corresponding change in $D$-value $\left(\mathrm{g} \mathrm{kg}^{-1}\right)$. The regression coefficient was $4.8 \pm 0.68 \mathrm{~g} \mathrm{~kg}^{-1}$ per 1 day delay $\left(p<0.001, \mathrm{R}^{2} 0.86\right)$. Thus, silage digestibility declines, on average, by 3.3 percentage units for each 1 week delay in harvest date. The rate of decline in herbage digestibility from the primary regrowth is similar to that for the primary growth. Therefore for each one week delay in harvesting of grass for ensilage, to sustain milk yield of dairy cows, carcass gain of beef cattle and finishing lambs and lamb birth weight from pregnant ewes, an additional 0.8-1.55 kg d-1 (depending on silage feed value and concentrate feed level, Table 8) $0.20 \mathrm{~kg} \mathrm{~d}^{-1}$ and $12.7 \mathrm{~kg}$ (during late pregnancy) of concentrate DM must be offered to lactating dairy cows, finishing beef cattle, finishing lambs, and pregnant ewes, respectively. 
Whilst date of harvest is negatively correlated with silage digestibility it is positively correlated with herbage yield. Keady and O'Kiely (1998) and Keady et al. (2000) reported that each one day delay in harvest increased herbage yield of the primary growth of predominantly perennial ryegrass swards by 145 and $151 \mathrm{~kg}$ DM respectively.

Lodging, or flattening, of the grass crop prior to harvest accelerates the rate of decline in herbage digestibility as harvest date is delayed. This accelerated decline in digestibility is due to the accumulation of dead leaf and stem at the base of the sward. Digestibility may decline by as much as 9 percentage units per week in severely lodged crops (O'Kiely et al. 1987).

\section{Sward type}

Normally, it is assumed that silage produced from old permanent pastures has a lower digestibility than silage produced from a perennial ryegrass sward. However, the negative impact of old permanent pasture on silage digestibility is dependent on botanical composition. If old permanent pastures are harvested at the correct stage of growth silage with a high feed value can be consistently produced.

A 2 year study was undertaken by Keating and O'Kiely (2000), using 4 harvests per year, to evaluate the effects of sward type on grass silage feed value. In the first year of the study, beef carcass output $\left(\mathrm{kg} \mathrm{ha}^{-1}\right)$ was similar for silage produced from old permanent pasture (45\% Poa spp, 26\% Agrostis spp, 10\% Lolium perenne, 6.5\% Alopecurus protensis, $2 \%$ Dactylis glomerate, $10.5 \%$ other) and a perennial ryegrass sward. Carcass output was lower for the silage from the old permament pasture in the second year of the study, but this was attributable to the fact that the silage produced from the first harvest of this pasture had a lower digestibility than that from the perennial ryegrass sward (swards closed the previous October) (Keating \& O’Kiely 2000).

The effects of sward type on feed value of silage harvested from the second re-growth (third harvest) (Keady et al. 1994) are presented in Table 9. Silage produced from an old permanent pasture ( $52 \%$ L perenne, $28 \%$ Agrostis stolonifera, $10 \%$ Poa spp, $10 \%$ Holcus lanatus) and that from a predominantly perennial ryegrass ( $L$ perenne) pasture resulted in silages that had similar (high) feed value, as determined by metabolisable energy (ME) concentrations (determined in-vivo) and intake when offered to growing cattle. Consequently, high feed-value silage can be produced from old permanent pasture provided it has a moderate level of perennial ryegrass and is ensiled at the correct stage of maturity using good ensiling management.

Table 9. Effect of sward type on silage composition, digestibility and intake

\begin{tabular}{|c|c|c|c|c|}
\hline & \multicolumn{2}{|c|}{ Sward type } & \multirow[b]{2}{*}{ SE } & \multirow[b]{2}{*}{ sig. } \\
\hline & Old permanent pasture & Perennial ryegrass & & \\
\hline \multicolumn{5}{|l|}{ Silage Composition } \\
\hline $\mathrm{pH}$ & 3.97 & 4.07 & 0.025 & NS \\
\hline Ammonia nitrogen $\left(\mathrm{g} \mathrm{kg}^{-1} \mathrm{~N}\right)$ & 75 & 74 & 2.4 & NS \\
\hline Metabolisable energy (MJ $[\mathrm{kg} \mathrm{DM}]^{-1}$ ) & 12.0 & 11.7 & 0.08 & $*$ \\
\hline Silage DM intake $\left(\mathrm{kg} \mathrm{d}^{1}\right)$ & 3.66 & 3.56 & 0.17 & NS \\
\hline
\end{tabular}

Keady et al. 1994

Perennial ryegrass varieties are classified according to heading date. Whilst the general recommendation is to harvest swards at approximately 50\% ear emergence, the actual date of emergence depends on the grass varieties in the sward and thus on their heading date. The effects of heading date (intermediate or late) of perennial ryegrass varieties, and date of harvest on the performance of beef cattle were evaluated in two studies by Steen (1992); the main results are presented in Table 10. The intermediate- and late-heading swards each consisted of 3 different varieties (with similar heading date) of perennial ryegrass. Whilst the mean heading date of the intermediate- and late-heading swards differed by 24 days (19 May and 12 June), herbage from the late-heading swards had to be ensiled within 8 days of that from the intermediate-heading swards to give the same silage digestibility and daily carcass gain of finishing beef cattle. If the harvest of the late-heading sward was delayed until $50 \%$ ear emergence the resulting silage DOMD would be $51 \mathrm{~g} \mathrm{~kg}^{-1}$ lower than the silage from the intermediateheading sward, consequently reducing silage DMI and carcass gain (from 0.63 to $0.40 \mathrm{~kg} \mathrm{~d}^{-1}$ ). Steen (1992) also reported no significant effect of either date of harvest of the primary growth or heading date (grass variety type) of the sward on total animal DM production. 
T.W.J. Keady et al. (2013) 22: 70-92

Table 10. Effect of sward heading date and harvest date on silage digestibility and animal performance

\begin{tabular}{|c|c|c|c|c|c|c|}
\hline \multirow[t]{3}{*}{ Performance } & \multicolumn{6}{|c|}{ Heading date $\times$ Harvest date } \\
\hline & \multicolumn{3}{|c|}{ Intermediate (19 May) } & \multicolumn{3}{|c|}{ Late (12 June) } \\
\hline & 20 May & 28 May & 5 June & 28 May & 5 June & 13 June \\
\hline Silage DOMD (g [kg DM] $]^{-1}$ ) & 725 & 685 & 640 & 722 & 679 & 652 \\
\hline Silage DM intake $\left(\mathrm{kg} \mathrm{d}^{-1}\right)$ & 6.8 & 6.2 & 6.3 & 6.6 & 6.4 & 5.9 \\
\hline Carcass gain $\left(\mathrm{kg} \mathrm{d}^{-1}\right)$ & 0.63 & 0.51 & 0.46 & 0.61 & 0.55 & 0.40 \\
\hline
\end{tabular}

DOMD: digestibility of organic matter, DM: dry matter

Steen 1992

Similarly, results from studies using small scale silos show that herbage from late-heading varieties (heading date 10 June) must be ensiled on 31 May to produce similar silage digestibility as that for intermediate-heading varieties (heading date 22 May) (Humphreys and O'Kiely 2007). However, these authors also noted that the rate of decline in digestibility with harvest date was not as rapid for late-heading varieties as for intermediate-heading varieties.

\section{Silage fermentation}

Relative to well-preserved silage, poorly preserved untreated silage with low lactic acid concentrations and high concentrations of ammonia nitrogen normally has lower digestibility. The reduction in DOMD in untreated silages due to deterioration in silage fermentation can be as high as 70 to $80 \mathrm{~g} \mathrm{~kg}^{-1}$ (Keady and Steen 1995). However for silages which are treated with an effective bacterial inoculant at ensiling, but which have poor fermentation characteristics (at feed out) there is no negative impact on digestibility or on subsequent animal performance (Keady and Steen 1995, Keady 1998).

\section{Fertilizer $\mathrm{N}$ application and wilting}

Application of excess fertilizer $\mathrm{N}$ alters silage digestibility. Increasing the rate of fertilizer $\mathrm{N}$ from 72 to $168 \mathrm{~kg} \mathrm{ha}^{-1}$ for the primary growth of predominantly perennial ryegrass swards reduced silage DOMD by $13 \mathrm{~g} \mathrm{~kg}^{-1}$ (Keady et al. 2000). The reduction in digestibility due to increased $\mathrm{N}$ fertilizer application is probably due to increased concentrations of acid detergent fiber and acid detergent lignin both of which are negatively correlated with digestibility (Keady et al. 2000). Increasing N fertilizer application increases herbage yield. Long et al (1991), Keady and O'Kiely (1998) and Keady et al. (2000) reported increased herbage yields of 10.2, 5.2 and 7.9 kg DM per kg increase in $\mathrm{N}$ fertilizer application, respectively.

Wilting reduces silage digestibility. From reviews of the literature, Wilkins (1984) and Rohr and Thomas (1984) reported average proportional reductions in silage DM digestibility, as assessed through sheep, of 0.031 and 0.041 , respectively. More recently Steen (1984a) and Gordon et al. (1999), using beef cattle, and Yan et al. (1996) and Keady et al. (1999), using dairy cows, reported proportional reductions in total diet digestibility of $0.03,0.045$, 0.02 and 0.02 , respectively. The decline in digestibility due to wilting is due to a loss of available nutrients and an increase in ash concentration. The rate of decline in digestibility due to wilting depends on the length of time between mowing and ensiling the herbage, and on soil contamination due to mechanical treatment. Rates of loss in digestibility vary from 2.3 to $9.0 \mathrm{~g} \mathrm{~kg}^{-1}$ per 10 hour wilting period. Thus each day (24 hours) of wilting will reduce silage DOMD by between 6 and $22 \mathrm{~g}(\mathrm{~kg} \mathrm{DM})^{-1}$.

\section{Wilting}

Wilting herbage prior to ensiling has many advantages including reduced effluent production, improved ensilability characteristics, reduced quantities of material for transport during ensiling and feed out, reduced freezing in cold climates and reduced straw requirement for bedding livestock. When wilting, a rapid wilt is desirable to minimize the decline in digestibility. The rate of water loss during wilting is primarily related to solar radiation and the weight, per unit area, of herbage in a swath (Wright 1997) and prevailing wind speed. Furthermore the lower the initial DM concentration of herbage at mowing the more water that has to be removed to increase the DM concentration by $100 \mathrm{~g} \mathrm{~kg}^{-1}$, e.g., if herbage is mowed at a DM concentration of $150 \mathrm{~g} \mathrm{~kg}^{-1}$ and dried to $250 \mathrm{~g}$ $\mathrm{kg}^{-1}$ then an extra $1 \mathrm{~kg}$ water per $1 \mathrm{~kg}$ DM is lost than is lost when herbage with an initial DM concentration of 200 $\mathrm{g} \mathrm{kg}^{-1}$ is dried to $300 \mathrm{~g} \mathrm{~kg}^{-1}$ (Wright et al. 2000). Reducing the density of the cut herbage involves covering the total ground area with herbage, which results in a higher drying rate. Herbage mown in auto-swaths (two swaths placed into one) has a much higher density than when the herbage is tedded out, thus management practices have a big impact on herbage drying rate (Table 11). The data in Table 11 show that to increase herbage DM from $160 \mathrm{~g} \mathrm{~kg}^{-1}$ to $250 \mathrm{~g} \mathrm{~kg}^{-1}$ required 65, 30 and 14 hours, respectively, for herbage that was mown in auto-swaths 
( $6 \mathrm{~m}$ width of herbage in one swath), single swaths ( $3 \mathrm{~m}$ width of herbage in one swath) or tedded out, to cover the total ground area, immediately post mowing, respectively.

Table 11. Effects of swath treatment and wilting period on herbage dry matter concentration $\left(\mathrm{g} \mathrm{kg}^{-1}\right)\left(\mathrm{Yield}_{\mathrm{i}}=29.4 \mathrm{t} \mathrm{ha} \mathrm{C}^{-1}\right)$

\begin{tabular}{|c|c|c|c|}
\hline & \multicolumn{3}{|c|}{ Wilting period (hours) } \\
\hline & 0 & 24 & 48 \\
\hline \multicolumn{4}{|l|}{ Swath treatment } \\
\hline Auto-swathed $^{+}$ & 160 & 192 & 228 \\
\hline Single swath & 160 & 229 & 317 \\
\hline Tedded out & 160 & 304 & 500 \\
\hline
\end{tabular}

Many studies have been undertaken on the effects of wilting on animal performance. Steen (1984a), from a review of 40 comparisons in the literature, Steen (1984a), from the mean of four studies, and O'Kiely (1994), from one study, reported that wilting herbage prior to ensiling resulted in an $18 \%, 5 \%$ and $13 \%$ increase in silage DMI, $41,-30$ and $-56 \mathrm{~g}$ change in daily live-weight gain and 30,40 and $31 \mathrm{~g}$ reduction in daily carcass gain of beef cattle, respectively. Using pregnant ewes, Chestnutt (1989) reported that wilting herbage at ensiling increased silage DMI by $7.4 \%$ whilst having no beneficial effect $(-0.05 \mathrm{~kg}$ ) on lamb birth weight. Similarly, using finishing lambs, Fitzgerald (1986) reported that wilting herbage at ensiling increased silage DMI by $26 \%$ but had no effect on daily carcass gain. More recently, data from dairy cows, from the mean of 11 comparisons (Patterson et al. 1996 and 1998), summarized by Keady (2000) show that rapid wilting of herbage from a DM concentration of $160 \mathrm{~g} \mathrm{~kg}^{-1}$ to $320 \mathrm{~g} \mathrm{~kg}^{-1}$ increased silage DMI by $17 \%$ and milk solid output by $3 \%$ but reduced cow feeding days per hectare by 174 days and milk output by $3074 \mathrm{I}$ ha $^{-1}$.

Many producers delay harvesting in showery weather conditions, with the intention of getting dry weather for wilting. However, in a prolonged period of showery weather crop digestibility is declining, whilst there may be opportunities to harvest and ensile as direct cut (unwilted). The effects of direct cutting, ensiling following water application (equivalent to rainfall) and wilting on the performance of dairy cows have been evaluated (Keady et al. 2002) and a summary is presented in Table 12. The wilted herbage was ensiled at a DM concentration of 277 $\mathrm{g} \mathrm{kg}^{-1}$ following a 30 hour wilting period. Wilting increased silage DMI but had no effect on milk yield or composition. Application of water at ensiling reduced herbage DM concentration at ensiling (131 v. $\left.187 \mathrm{~g} \mathrm{~kg}^{-1}\right)$ but had no effect on silage DMI or on milk yield or composition, illustrating that ensiling herbage direct cut (unwilted) during showery conditions has no negative impact on animal performance.

Table 12. Effect of herbage dry matter at ensiling on dairy cow performance

\begin{tabular}{|c|c|c|c|c|c|}
\hline & \multicolumn{3}{|c|}{ Herbage dry matter at ensiling $\left(\mathrm{gkg}^{-1}\right)$} & \multirow[b]{2}{*}{ SE } & \multirow[b]{2}{*}{ sig. } \\
\hline & 131 & 187 & 277 & & \\
\hline Silage dry matter intake $\left(\mathrm{kg} \mathrm{d}^{-1}\right)$ & 9.7 & 9.6 & 13.6 & 0.026 & $* * *$ \\
\hline Milk yield $\left(\mathrm{kg} \mathrm{d}^{-1}\right)$ & 20.1 & 20.0 & 20.0 & 0.14 & NS \\
\hline Fat $\left(\mathrm{g} \mathrm{kg}^{-1}\right)$ & 39.9 & 40.1 & 41.3 & 0.53 & NS \\
\hline Protein $\left(\mathrm{g} \mathrm{kg}^{-1}\right)$ & $33.2^{b}$ & $32.8^{a}$ & $34.2^{c}$ & 0.13 & $* * *$ \\
\hline
\end{tabular}

The data clearly show that whilst wilting reduces effluent production, wilting increases daily silage DMI and reduces the number of animal feeding days and the output of animal product per hectare. 


\section{Fertilizer management Nitrogen}

To achieve the maximum response to fertilizer $\mathrm{N}$, soil $\mathrm{P}, \mathrm{K}$ and $\mathrm{pH}$ need to be at optimum levels. The response in herbage yield to inputs of fertilizer $\mathrm{N}$ is presented in Table 13. The response varied from 5.2 to $10.2 \mathrm{~kg}$ herbage DM per $1 \mathrm{~kg} \mathrm{~N}$. The response varies depending on the base level of nitrogen applied, prevailing weather conditions and harvest date. Fertilizer $\mathrm{N}$ also affects herbage composition. Increasing the rate of fertilizer $\mathrm{N}$ applied increases herbage crude protein concentration and reduces herbage DM concentration (Keady and O'Kiely 1996, 1998; Keady et al. 2000) thus presenting a greater challenge for silage preservation. Furthermore, increasing $\mathrm{N}$ fertilizer application can reduce the concentration of WSC (Wilson and Flynn 1979, Keady et al. 2000), probably associated with the synthesis of WSC to plant structural components with increased herbage yield causing a reduction in the capture of solar radiation per unit of plant mass. Therefore, applying excess fertilizer $\mathrm{N}$ can have a negative impact on herbage ensilability. However, an inadequate level of fertilizer $\mathrm{N}$ reduces herbage yield and the crude protein concentration of the subsequent silage. Furthermore, inadequate $\mathrm{N}$ fertilizer application may result in a clostridial fermentation, as determined by butyric acid, due to inadequate concentrations of nitrate in the silage (Jaakkola et al. 1999).

The optimum level of $\mathrm{N}$ for the first, second and third harvests from predominantly perennial ryegrass swards are 120,100 and $80 \mathrm{~kg} \mathrm{ha}^{-1}$ respectively (Keady et al. 1998). When paddocks are closed for silage after being grazed it should be assumed that between 20 and $30 \%$ of the $\mathrm{N}$ applied for the most recent grazing is available for the silage crop.

Table 13. Effect of fertilizer (N) application on herbage dry matter (DM) yield in the primary growth

\begin{tabular}{lcc}
\hline Source & $\begin{array}{c}\text { Range in N application } \\
\left(\mathrm{kg} \mathrm{ha}^{-1}\right)\end{array}$ & kg DM per kg nitrogen \\
\hline Long et al. (1991) & $100-150$ & 10.2 \\
Keady and O'Kiely (1998) & $120-168$ & 5.2 \\
Keady et al. (2000) & $72-168$ & 7.9 \\
\hline
\end{tabular}

\section{Potassium}

Large quantities of $\mathrm{K}$ are required, and removed, by silage crops. Up to $26 \mathrm{~kg}$ of $\mathrm{K}$ are removed per tonne of herbage dry matter (Keady and O'Kiely 1998). It has been suggested previously that there is a strong correlation between soil K concentration and the subsequent buffering capacity of Lucerne ( $M$ sativa) (Muck and Walgenbach 1985 ) and that this may have a negative impact on the composition and feed value of the resultant silage. A study was undertaken by Keady and O'Kiely (1998) to evaluate the effects of fertilizer K on herbage yield, composition and feed value. Increasing the level of fertilizer $\mathrm{K}$ increased herbage yield at both the first and second harvests (Table 14). The mean response, between the two harvests, was $4.5 \mathrm{~kg}$ herbage DM per $1 \mathrm{~kg} \mathrm{~K}$ applied. Application of excess $\mathrm{K}$ can result in luxury uptake of $\mathrm{K}$ by the crop. However excess $\mathrm{K}$ application has no effect on herbage composition or ensilability (Table 14) or on predicted feeding value of the resultant silage (Keady and O'Kiely 1998). The quantity of fertilizer $\mathrm{K}$ that should be applied for silage production depends on the soil potassium index and expected herbage yield (thus crop requirements).

Table 14. Effect of potassium (applied on 2 March) on herbage yield at the first and second harvest (index $=3 \mathrm{~K}$ in soil) and composition of the herbage from the first harvest

\begin{tabular}{|c|c|c|c|c|c|c|c|}
\hline & \multicolumn{5}{|c|}{ Potassium applied $\left(\mathrm{kg} \mathrm{ha}^{-1}\right)$} & \multirow[b]{2}{*}{ SE } & \multirow[b]{2}{*}{ sig. } \\
\hline & 0 & 60 & 120 & 180 & 240 & & \\
\hline \multicolumn{8}{|l|}{ Herbage dry matter yield (t ha ${ }^{-1}$ ) } \\
\hline - first harvest & 6.31 & 6.57 & 6.74 & 6.93 & 6.93 & 0.091 & $* * *$ \\
\hline - second harvest & 2.56 & 2.73 & 2.83 & 2.94 & 2.99 & 0.056 & $* * *$ \\
\hline Dry matter $\left(\mathrm{g} \mathrm{kg}^{-1}\right)$ & 179 & 170 & 169 & 171 & 169 & 3.1 & NS \\
\hline Buffering capacity ( $\left.\mathrm{mEq}\left[\mathrm{kg} \mathrm{DM}^{-1}\right]\right)$ & 430 & 442 & 454 & 445 & 442 & 9.7 & NS \\
\hline Water soluble carbohydrate (g[kg DM $\left.\left.{ }^{-1}\right]\right)$ & 101 & 93 & 94 & 100 & 96 & 2.7 & NS \\
\hline Nitrate (mg [kg DM $\left.\left.{ }^{-1}\right]\right)$ & 35 & 18 & 18 & 13 & 15 & 9.1 & NS \\
\hline
\end{tabular}

Keady and O'Kiely 1998 


\section{Chop length}

Whilst chop length has no effect on silage DMI or on the performance of beef cattle (Steen 1984a) or dairy cows (Gordon 1982), chop length affects the intake characteristics of silage when offered to pregnant ewes (Chestnutt 1989) and finishing lambs (Fitzgerald 1996). Reducing silage chop length, determined by harvester type, increased silage DMI and live-weight gain of finishing lambs by up to $34 \%$ and $242 \%$, respectively (Fitzgerald 1996). When offered to pregnant ewes, reducing silage chop length by use of a precision chop harvester relative to single chopping, increased silage DMI and, consequently, increased lamb birth weight by $0.25 \mathrm{~kg}$ and reduced weight loss by ewes during pregnancy by $4.9 \mathrm{~kg}$ (Chestnutt, 1989).

In a recent study (Keady and Hanrahan 2008) big-bale and precision-chop silage systems were compared in both the first and second harvests using herbage that had been ensiled at a mean dry matter concentration of $249 \mathrm{~g}$ $\mathrm{kg}^{-1}$ (Table 15). Results showed that system of ensiling had little impact on silage DMI or on lamb birth weight. However, weaning weight was $1.8 \mathrm{~kg}$ higher for lambs from ewes that were offered the precision-chop silage during pregnancy and was due to higher daily live weight gain between birth and 10 weeks of age.

Table 15. Effect of silage harvest system on ewe performance

\begin{tabular}{|c|c|c|c|}
\hline & & \multicolumn{2}{|c|}{ Harvest system } \\
\hline & & Big bale & Precision chop \\
\hline \multicolumn{2}{|c|}{ Silage dry matter intake $\left(\mathrm{kg} \mathrm{d}^{-1}\right)$} & 0.95 & 0.97 \\
\hline \multirow[t]{2}{*}{ Lamb weight } & - birth (kg) & 4.7 & 4.8 \\
\hline & - weaning (kg) & 32.5 & 34.3 \\
\hline \multirow[t]{2}{*}{ Lamb weigh gain $\left(\mathrm{g} \mathrm{d}^{-1}\right)$} & - 0 to 5 weeks & 314 & 338 \\
\hline & - 5 to 10 weeks & 314 & 332 \\
\hline
\end{tabular}

Keady and Hanrahan 2008

\section{Additive management}

In the past the principal objective in applying a silage additive was to improve silage fermentation under difficult ensiling conditions. This was achieved be applying acid or sugar-based additives. However, more recent research has shown that the use of effective bacterial inoculants can substantially improve animal performance without necessarily altering the fermentation quality of the silage at the time of feeding (Gordon 1980; Keady and Steen 1994, 1995).

Animal performance is the most important measure of the efficacy of a silage additive as producers are paid for animal product, and not for the preservation quality of silage as measured by conventional laboratory analysis. When applying additives it is important to apply them at the correct rate, taking account of changes in the moisture concentration in the herbage being ensiled. For example, if the dry matter concentration of the herbage is increased from 180 to $250 \mathrm{~g} \mathrm{~kg}^{-1}$, the fresh weight of grass will be reduced from 29.5 to $21 \mathrm{t} \mathrm{ha}^{-1}$ consequently reducing additive requirement per hectare by $40 \%$.

Many studies have been undertaken to evaluate different classes of additives with respect to the performance of beef cattle and lactating dairy cattle. From a review of 11 published studies in which molasses (mean application rate of $15.8 \mathrm{I} \mathrm{t}^{-1}$ of herbage) and formic acid treated silages were compared with untreated silages Keady (1996) concluded that whilst molasses treatment improved silage fermentation it did not increase animal performance. In the same review Keady (1996) concluded that formic acid treatment increased animal performance by $17 \%$. From a review of 95 comparisons in which silages made with different types of additives were compared to untreated silages Keady (1998) concluded that use of proven effective bacterial inoculants, under a wide range of ensiling conditions, or formic acid, under difficult conditions, increased the performance of lactating dairy cows and finishing beef cattle. Whilst use of molasses, sulphuric acid and enzyme-based additives improved silage fermentation, they had no significant effect on animal performance. Patterson et al. (1998) reported similar improvements in dairy cow performance from inoculant treatment of direct cut (unwilted) and wilted herbage at ensiling. 


\section{Mode of action of inoculants}

Whilst inoculant treatment may have little effect on silage fermentation at the time of feed out, numerous studies (Gordon 1989a, Keady and Steen 1994, 1995) have shown that inoculant treatment results in a more rapid fermentation, as measured by the fall in $\mathrm{pH}$ immediately post-ensiling relative to untreated herbage. This more rapid fermentation due to inoculant treatment suppresses proteolysis and deamination processes of herbage protein (Heron et al. 1987) and results in higher retention of soluble components. From a review of 40 comparisons in the literature, in which the organic matter digestibility of inoculated and untreated silages were compared, Keady (1991) concluded that inoculant treatment increased organic matter digestibility by $2 \%$. In a more recent series of five comparisons Keady et al. (1994) and Keady and Steen $(1994,1995)$ concluded that the use of an effective inoculant containing a single strain of $L$. plantarum substantially increased silage digestibility (organic matter digestibility) by $33 \mathrm{~g} \mathrm{~kg}^{-1}$, particularly where silage was from difficult-to-ensile herbage, primarily due to dramatic improvements in the digestibility of the fibre fractions. The same authors concluded that the improvement in animal performance following treatment with an effective inoculant can be attributed to the retention of greater proportions of the more soluble components of the plant due to a more rapid and efficient fermentation process within the silo. This subsequently results in increased silage digestibility and a reduction in the extent of protein break down.

\section{Alternative forages}

Traditionally in many parts of Europe, Australia, New Zealand and North America, grass silage was offered to cattle and sheep during the indoor feeding period. However in recent times other ensiled forages, such as maize $(Z$. mays) and whole crop wheat (T. aestivum), have increased in popularity and have partially replaced grass silage in the diet.

\section{Maize silage}

Major developments, both in plant breeding and in agronomic practice, have enabled the consistent production of high yields of maize forage in areas in which it was not possible to grow the crop 20 to 30 years ago. For example, the dry matter yield of maize crops produced in Northern Ireland have increased by $300 \%$, to $12.2 \mathrm{t} \mathrm{ha}^{-1}$, primarily due to plant breeding efforts (Keady 2005). Developments in agronomic practices, particularly the complete cover plastic mulch system (CCPM), which was developed in Ireland, have further increased yield potential and the degree of maturity attained by crops grown in more temperate climates. The CCPM system involves covering the crop with a thin clear film (6 to 9 microns) through which the plant emerges at approximately the 6 leaf stage. Use of this system increases forage yield by up to $50 \%$ as it enables later maturing varieties to be planted at earlier sowing dates (Keady 2005, Keady and Hanrahan 2013). Keady (2005) concluded that silage produced from maize sown under the CCPM system, because of its higher yield potential, could be produced at the same cost as grazed grass, but if sown in the open the cost of silage from maize was $30 \%$ and $20 \%$ greater than that of grazed grass and 3-cut grass silage, respectively.

\section{Effects of maize on beef cattle performance}

Keady (2005) concluded, from the mean of 34 comparisons in which grass silage was partially or totally replaced with maize silage, that maize silage significantly increased forage DMI $\left(1.5 \mathrm{~kg} \mathrm{~d}^{-1}\right)$ and performance of lactating dairy cows, as determined by milk yield $\left(+1.4 \mathrm{~kg} \mathrm{~d}^{-1}\right)$, fat concentration $\left(+0.6 \mathrm{~g} \mathrm{~kg}^{-1}\right)$ and protein concentration $(+0.8$ $\left.\mathrm{g} \mathrm{kg}^{-1}\right)$. Keady (2005) also concluded, from the mean of 9 comparisons in which grass silage was partially or totally replaced with maize silage, that maize silage significantly increased forage DMI $\left(1.5 \mathrm{~kg} \mathrm{~d}^{-1}\right)$ and performance of beef cattle, as determined by live-weight gain $\left(+0.23 \mathrm{~kg} \mathrm{~d}^{-1}\right)$, carcass gain $\left(+0.11 \mathrm{~kg} \mathrm{~d}^{-1}\right)$ and carcass weight $(+12 \mathrm{~kg})$. In the same review Keady (2005) concluded, based on dairy cow studies, that in order to achieve optimum levels of performance from dairy cattle the maize crop should be harvested and ensiled at a dry matter concentration of approximately $300 \mathrm{~g} \mathrm{~kg}^{-1}$. More recently, using beef cattle, Keady et al. (2013) concluded that the response to the inclusion of maize silage in the forage component of the diet, in terms of daily carcass gain, was dependant on stage of maturity of the maize at harvest and level of inclusion in the diet. Keady et al. (2013) concluded that maize silage with a dry matter of $304 \mathrm{~g} \mathrm{~kg}^{-1}$, when offered ad libitum as the sole forage, increased daily carcass gain by $31 \%$ due to a combination of increased ME intake and improved efficiency of ME utilization and produced carcasses with whiter fat. However, when offered as $50 \%$ of the forage component of the diet, stage of maturity (maize silage with dry matter concentrations of 217 and $304 \mathrm{~g} \mathrm{~kg}^{-1}$, respectively) had no significant effect on beef cattle performance. 
As outlined by Keady (2005) and Keady et al. (2007, 2008a and 2013) when the cost of concentrate is high relative to the price of animal product, one of the potential benefits of including an alternative forage in diets based on grass silage is the potential to maintain animal performance whilst reducing concentrate feed level. Keady $(2005)$ and Keady et al. $(2007,2013)$ reported potential concentrate sparing effects of up to $2.4 \mathrm{~kg}$ per animal daily when maize silage was included in the diet of beef cattle; the effect depended on level of maize inclusion in the diet and crop maturity at harvest. For lactating dairy cows Keady (2005) concluded including maize silage in grass silage based diets had a potential concentrate sparing effect of up to $5.0 \mathrm{~kg}$ per cow daily

\section{Effects of maize on performance of pregnant ewes}

In many parts of Ireland, the UK and other sheep producing regions ewes are normally housed during the winter feeding period and offered ensiled forage. Whilst many studies have shown that including maize silage in the forage component of diets offered to beef cattle and dairy cows increases animal performance (Keady 2005, Keady et al. 2007, 2008a, 2013) few studies have been undertaken to evaluate the effects on the performance of pregnant ewes or finishing lambs. One of the characteristics of maize silage is its low crude protein concentration (consistently less than $100 \mathrm{~g}\left(\mathrm{~kg} \mathrm{DM}^{-1}{ }^{-1}\right.$, which declines as maturity increases (Keady et al. 2003, 2008a, 2013) and may impact on its ability to meet the protein requirements of ewes in early and mid pregnancy. Robinson (1983) concluded that forages offered during early and mid pregnancy should contain a minimum crude protein concentration of $10 \mathrm{~g}$ per $\mathrm{MJ}$ of $\mathrm{ME}$, otherwise the forage needs to be supplemented with protein to meet requirements. Keady and Hanrahan (2008) evaluated the effects of replacing grass silage with maize silages differing in maturity at harvest and supplemented with either 0 or $200 \mathrm{~g}$ soyabean meal during mid and late pregnancy. Replacing grass silage with maize had no effect on ewe performance at lambing or on lamb birth or weaning weights. Supplementation of maize silage with soyabean meal during mid and late pregnancy increased ewe condition at lambing but did not alter lamb performance. More recently Keady and Hanrahan (2009a) evaluated the effects maturity of maize at harvest, grass silage feed value, soyabean meal supplementation during mid and late pregnancy, and concentrate supplementation during late pregnancy on ewe and lamb performance (Table 16). Increasing maturity of maize significantly increased ewe weight at lambing. Whilst supplementation with soyabean meal increased ewe weight at lambing and lamb birth weight, there was no effect on lamb weight at weaning (14 weeks). Both studies (Keady and Hanrahan 2008, 2009a) indicated that increasing maturity of maize at harvest tended to increase lamb weaning weight by about $1 \mathrm{~kg}$. Keady and Hanrahan (2009d) offered pregnant ewes maize silage as the basal forage and concluded that there is no benefit to supplementing ewes with protein in mid pregnancy and that total concentrate supplementation during late pregnancy for twin bearing ewes could be reduced to 10 kg soyabean (with mineral and vitamin supplementation) meal without having any negative impact on ewe or subsequent lamb performance.

These studies show that maize silage can replace high feed-value grass silage in the diet of ewes in mid and late pregnancy. Maize silage, whilst low in crude protein, can be offered as the sole forage without protein supplementation until late pregnancy (final 6 to 7 weeks). Increasing the maturity of maize at harvest tended to increase lamb weaning weight by $1 \mathrm{~kg}$.

Table 16. The effects of maturity of maize silage, grass silage feed value and concentrate level on animal performance

\begin{tabular}{|c|c|c|c|c|c|c|c|c|c|c|c|c|c|}
\hline \multirow[b]{3}{*}{ Soya $(\mathrm{S})^{1} / \operatorname{conc}(\mathrm{C})^{2}$} & \multicolumn{4}{|c|}{ Maize silage (MS) dry matter } & \multicolumn{5}{|c|}{ Grass silage feed value (GS) } & \multirow[b]{3}{*}{ sem } & \multirow{2}{*}{\multicolumn{3}{|c|}{ sig. $^{3}$}} \\
\hline & \multicolumn{2}{|c|}{ Low } & \multicolumn{2}{|c|}{ High } & \multicolumn{2}{|c|}{ Low } & \multicolumn{3}{|c|}{ High } & & & & \\
\hline & $0 / 15$ & $200 / 15$ & $0 / 15$ & $200 / 15$ & $0 / 15$ & $0 / 25$ & $0 / 5$ & $0 / 15$ & $0 / 25$ & & MS & $\mathrm{S}$ & GS \\
\hline Ewe weight $(\mathrm{kg})^{4}$ & 63.0 & 68.6 & 68.2 & 76.6 & 61.2 & 61.6 & 70.4 & 73.6 & 73.6 & 2.15 & $* *$ & $* *$ & $* * *$ \\
\hline Litter size (lambs/ewe) & 2.09 & 1.74 & 2.04 & 2.03 & 1.95 & 1.80 & 1.62 & 1.65 & 1.81 & 0.171 & NS & NS & NS \\
\hline \multicolumn{14}{|l|}{ Lamb weight (kg) } \\
\hline - birth & 4.62 & 4.92 & 4.65 & 5.29 & 4.60 & 4.56 & 4.85 & 5.13 & 5.13 & 0.168 & NS & $* *$ & $* * *$ \\
\hline - weaning & 33.4 & 32.8 & 34.1 & 34.3 & 33.6 & 32.1 & 34.0 & 35.0 & 34.3 & 1.05 & NS & NS & $*$ \\
\hline Lamb weight gain $\left(\mathrm{g} \mathrm{d}^{-1}\right)$ & 296 & 289 & 303 & 299 & 300 & 284 & 301 & 309 & 302 & 10.17 & NS & NS & NS \\
\hline Age at slaughter (days) & 162 & 160 & 159 & 141 & 170 & 175 & 170 & 154 & 164 & 9.0 & NS & NS & $P=0.08$ \\
\hline Dressing proportion & 0.43 & 0.43 & 0.42 & 0.43 & 0.43 & 0.43 & 0.42 & 0.44 & 0.43 & 0.009 & NS & NS & NS \\
\hline Carcass weight (kg) & 18.9 & 18.2 & 19.1 & 18.7 & 18.8 & 19.1 & 19.4 & 19.6 & 19.2 & 0.43 & NS & NS & NS \\
\hline Fat classification ${ }^{5}$ & 3.1 & 2.8 & 3.0 & 2.9 & 2.8 & 3.0 & 2.9 & 3.0 & 2.9 & 0.12 & NS & $p=0.07$ & NS \\
\hline
\end{tabular}

${ }^{1}$ Soya $=\mathrm{g} \mathrm{d}^{-1}$ for duration of the study. ${ }^{2}$ Total concentrate $(\mathrm{kg})$ in late pregnancy. ${ }^{3}$ There were no significant concentrate $(\mathrm{C})$ effects or maize silage $\mathrm{x}$ soyabean meal or grass silage $\mathrm{x} C$ level interactions. ${ }^{4}$ Weight post lambing.

${ }^{5}$ Fat classification (scale 1 to 5 ; where 1 = thin, 5 = fat)

Keady and Hanrahan 2009a 


\section{Effects of maize silage on performance of finishing lambs}

Prime lamb production is seasonal and grass-based with lambing normally targeted to coincide with the start of grass growth in spring (Keady and Hanrahan 2013). However, in Ireland $20 \%$ of the lamb kill occurs during the first 3 months of the year, which helps to maintain seasonality of supply of lamb to the market. As grass growth rate during the winter declines to as low as $0 \mathrm{~kg} \mathrm{~d}^{-1}$ a large proportion of these lambs are finished on high concentrate diets, or diets containing conserved forages and concentrates.

Keady and Hanrahan (2013) reported that increasing the maturity of maize at ensilage, as indicated by starch con-

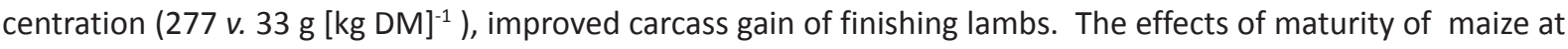
ensilage, grass silage feed value and concentrate feed level on the performance of finishing lambs from two studies (Keady and Hanrahan 2012b, 2013) are presented in Table 17. Maize silage replaced high feed-value grass silage and was better than medium feed-value grass silage (DOMD $688 \mathrm{~g} \mathrm{~kg}^{-1}$ ) in the diet of finishing lambs, as indicated by daily carcass gain, regardless of concentrate feed level. As concentrate feed level increased the response to forage feed-value declined, but was still evident when concentrates accounted for up to $70 \%$ of total DMI. Keady and Hanrahan (2012b and 2013) reported that replacing medium feed-value grass silage with maize silage resulted in a potential concentrate sparing effect of up to $0.48 \mathrm{~kg}$ per lamb daily.

Table 17. Effects of forage type and concentrate feed level on lamb performance

\begin{tabular}{|c|c|c|c|c|}
\hline & \multirow[b]{3}{*}{ Conc $\left(\mathrm{kg} \mathrm{d}^{-1}\right)$} & \multicolumn{3}{|c|}{ Forage } \\
\hline & & \multicolumn{2}{|c|}{ Grass silage } & \multirow[t]{2}{*}{ Maize } \\
\hline & & Medium & High & \\
\hline \multirow[t]{4}{*}{ Total DM intake $\left(\mathrm{kg} \mathrm{d}^{-1}\right)$} & 0.3 & 0.9 & 1.1 & 1.1 \\
\hline & 0.7 & 1.1 & 1.2 & 1.1 \\
\hline & 1.0 & 1.2 & 1.3 & 1.3 \\
\hline & ad libitum & & 1.4 & \\
\hline \multirow[t]{4}{*}{ Carcass weight (kg) } & 0.3 & 17.3 & 20.6 & 20.2 \\
\hline & 0.7 & 21.1 & 22.4 & 22.1 \\
\hline & 1.0 & 22.8 & 24.2 & 23.3 \\
\hline & ad libitum & & 26.6 & \\
\hline \multirow[t]{4}{*}{ Carcass gain $\left(\mathrm{g} \mathrm{d}^{-1}\right)$} & 0.3 & 14 & 62 & 59 \\
\hline & 0.7 & 72 & 91 & 87 \\
\hline & 1.0 & 98 & 119 & 107 \\
\hline & ad libitum & & 150 & \\
\hline
\end{tabular}

Keady and Hanrahan 2012b, 2013

\section{Whole crop wheat}

There has been increased interest in the production of whole-crop cereal silage for feeding to beef and dairy cattle in recent years. The increased interest in this crop is due primarily to the similar cost of production relative to grass silage and the perceived potential benefits in forage DMI and subsequently animal performance. Whole crop wheat is predominantly ensiled and fermented at DM concentrations ranging from 250 to $450 \mathrm{~g} \mathrm{~kg}^{-1}$. However, whole crop wheat can also be ensiled at high DM concentrations, ranging from 550 to $800 \mathrm{~g} \mathrm{~kg}^{-1}$, and treated with either urea or a urea-based additive to encourage an alkaline environment. Recent developments in the ensiling of whole crop cereals involves the ensiling of crops at high DM concentrations $\left(700-800 \mathrm{~g} \mathrm{~kg}^{-1}\right)$, harvested through a forage harvester fitted with a grain processor and ensiled with a urea-based additive.

\section{Effect of whole crop wheat inclusion on animal performance}

From a review of 20 comparisons involving dairy cows and 7 comparisons involving finishing beef cattle Keady (2005) concluded that whilst partially or totally replacing grass silage with whole crop wheat, either fermented or urea treated, increased forage DMI it had no beneficial effect on the yields of milk or of fat plus protein from dairy cows, or on carcass gain of beef cattle. Similarly, O'Kiely (2011) noted that replacing low feed-value grass silage with triticale reduced carcass gain of finishing beef cattle. However, Walsh et al. (2008) noted that replacing a poorly preserved, low feed-value grass silage $(\mathrm{pH}$ and concentrations of $\mathrm{DM}$, ammonia nitrogen and DOMD of $4.3,174 \mathrm{~g} \mathrm{~kg}^{-1} 155 \mathrm{~g} \mathrm{~kg}^{-1} \mathrm{~N}$ and $634 \mathrm{~g}^{\left(\mathrm{kg} \mathrm{DM}^{-1}\right)}$, respectively) with whole crop wheat increased performance of finishing beef cattle. 


\section{Forage legume and kale silage}

Previously legume forages, e.g., red clover (T. pratense) and lucerne (M. sativa), were regarded as being unsuitable for ensiling due to having a low concentration of WSC and a high buffering capacity. However, advances in silage technology have enabled these forages to be ensiled as high-protein forage for livestock. Results from a recent study (Marley et al. 2007) of the effects of forage type (red clover, lucerne, kale, peas) showed that live-weight gain, food conversion and nitrogen use efficiency were higher in lambs offered the red clover, lucerne and kale ( $B$ oleracea) silages compared with those offered low feed-value hybrid-ryegrass silage (ME $10 \mathrm{MJ} \mathrm{kg}^{-1} \mathrm{DM}$ ). As ruminants are typically viewed as inefficient converters of dietary protein, the data presented in Table 18 show the potential of using these forages to enable more sustainable and nutrient-efficient livestock systems.

Table 18. Effect of forage type on lamb live-weight gain ( $L W G \mathrm{~g} \mathrm{~d}^{-1}$ ), food conversion efficiency (FCE) [kg live-weight gain (DM consumed ${ }^{-1}$ ); $\mathrm{kg} \mathrm{kg}^{-1}$ ] and nitrogen use efficiency (NUE) [live-weight gain ( $\mathrm{N}$ consumed) ${ }^{-1} ; \mathrm{kg} \mathrm{kg}^{-1}$ ] of finishing lambs fed different silages.

\begin{tabular}{lcccccc}
\hline Trait & Ryegrass & Red clover & Lucerne & Kale & s.e.d. & Level of significance \\
\hline LWG & 36 & 135 & 135 & 100 & 8.9 & $* * *$ \\
& & & & & & $* .136^{\mathrm{a}}$ \\
FCE & $0.053^{\mathrm{b}}$ & $0.133^{\mathrm{a}}$ & $0.130^{\mathrm{a}}$ & & 0.0081 & $* * *$ \\
NUE & $2.9^{\mathrm{c}}$ & $4.4^{\mathrm{b}}$ & $3.7^{\mathrm{b}}$ & $5.3^{\mathrm{a}}$ & 0.36 & $* * *$ \\
\hline
\end{tabular}

Marley et al. 2007

Despite the potential for these ensiled alternative forages to contribute to livestock systems there has been relatively little research into their effects on the performance of beef cattle or sheep. However a number of studies have been undertaken to evaluate the effects of legumes on the performance of dairy cows which have been reviewed by Dewhurst (2012).

\section{Red clover and lucerne}

Typically, legumes have a higher buffering capacity than grasses (Pitt 1990), and the pH of lucerne silage tends to be higher than that of red clover silage (McDonald et al. 1991) due to its higher buffering capacity (typical buffering capacities of red clover and lucerne are 560 and $480 \mathrm{mEq}\left(\mathrm{kg} \mathrm{DM}^{-1}\right.$ respectively (Wilkinson 1978)) and lower amounts of fermentable substrate (Raguse and Smith 1966). The conservation of red clover and lucerne as silage in areas within the EU that have high rainfall often necessitates harvesting at a DM concentration less than 300 $\mathrm{g} \mathrm{kg}^{-1}$. The dry matter concentration of legumes at ensiling can affect the fermentation and quality of the silage produced. Fychan et al. (2002a) wilted red clover and lucerne for either 27, 51 or 75 hours and reported that increasing the wilting period increased $\mathrm{pH}$ and WSC concentration and reduced the concentrations of ammonia- $\mathrm{N}$ and lactate in the silages, and that the wilting rate of lucerne was higher than that of red clover.

Legumes for ensiling should be harvested at the stage of maturity that maximises crude protein concentration while ensuring adequate sugars for fermentation. As legumes mature, the concentration of crude protein declines. The different stages of maturity can be determined using the formula and phenological-staging scheme described by Kalu and Fick (1981) for red clover, and modified for lucerne by Ohlsson and Wedin (1989). Research on the effect of stage of maturity at harvest on the yield and chemical composition of red clover during three harvest years showed that allowing red clover to mature to early-late bud stage before taking the first harvest gave a $20 \%$ increase in dry matter yield and a $32 \%$ increase in protein yield per hectare compared to harvesting at a late vegetative stage for all harvest years (Fychan et al. 2002b). A study on the effect of stage of maturity at harvest on the yield and chemical composition of lucerne during three harvest years showed that it was advantageous to allow the first harvest to be taken when the stage of growth is between early and late bud (Fychan et al. 2002b).

Proteolysis during ensiling is influenced by forage species. Protein degradation is lower when red clover is ensiled compared to lucerne (Papadopoulos and McKersie 1983, McKersie 1985, Jones et al. 1995a) as red clover contains an enzyme, polyphenol oxidase, that inhibits proteolysis, both in the silo and in the rumen (Jones et al. 1995b, Broderick and Albrecht 1997). Fychan et al. (2002c) showed that ensiling lucerne and red clover in a clamp silo, when compared to round bales, resulted in lower $\mathrm{pH}$, and lower concentrations of free amino acids and WSC, and higher concentrations of lactate in both lucerne and red clover silages. Marley et al.,(2003) concluded that the optimum ratio to sow red clover lucerne bi-crop, based on the resultant silage analysis, was 50:50 red clover:lucerne due to the improved wilting properties of lucerne and the reduced proteolysis of ensiled red clover. 
Ensiled legumes can increase growth rate in lambs due to higher forage DMI and improved nitrogen utilisation efficiency relative to grass silage (Fraser et al. 2000, Speijers et al. 2005a). However Speijers et al. (2005a) reported that the intake and growth rate by finishing lambs offered ensiled lucerne was the same as that of lambs fed ryegrass silage. Using twin bearing ewes Speijers et al. (2005b) reported higher food intake for lucerne silage compared to ryegrass silage.

Incorporating red clover silage into the winter diet of an upland beef system increased live-weight gain relative to animals offered low feed value grass silage (DOMD $586 \mathrm{~g} \mathrm{~kg}^{-1}$ ) (Fraser et al. 2007). In the same study, meat from the steers fed on red clover silage over winter had a higher lipid oxidation than steers grazing permanent pasture supplemented with grass silage (previously ensiled from that pasture) probably related to the vitamin E content of the loin muscle, however there were no differences between treatments in the sensory properties (texture, juiciness or flavor) of the beef. With respect to vitamin E concentrations, Beeckman et al. (2010) reported that treating ryegrass, red clover or white clover with formic acid or lactic acid bacteria at ensiling did not affect vitamin $\mathrm{E}$ concentration. Furthermore Beeckman et al. (2010) showed that ryegrass had higher concentrations of vitamin E than clovers and that still difference remained following wilting and ensiling. Studies with beef cattle offered ensiled lucerne showed higher intakes for beef cattle fed ensiled Lucerne relative to grass silages (Pocknee and Campling 1981, Doyle and Thomson 1985, Han et al. 2006). The higher intakes recorded for ruminants offered legume silages relative to grass silage have been attributed to legume silages having a higher passage rate due to higher rumen outflow rate (Dewhurst et al. 2003b).

One constraint to the use of red clover in sheep systems is the presence of phyto-oestrogen compounds, which reduce ewe fertility (Barrett et al. 1965). Phyto-oestrogens, e.g., formononetin, are a group of naturally-occurring plant-derived non-steroidal compounds that have the ability to cause oestrogenic and/or anti-oestrogenic effects in livestock (Benassayag et al. 2002). Thomson (1975) concluded that feeding ensiled red clover could still reduce ewe fertility when offered at rates as low as $25 \%$ of the diet. In a more recent study, ewes being offered a diet containing $50 \%$ red clover silage were found to have isoflavones in body tissues (Urpi-Sarda et al. 2008).Sarelli et al. (2003) reported that the oestrogen content of red clover silage was higher than the raw material and that the type of silage inoculant used during ensiling affected phyto-oestrogen levels in the resultant silage. There are contradictory reports on the effect of red clover silage on cattle. Kallela et al. (1984) reported that plant oestrogens in a pure red clover silage (with $0.56 \%$ formononetin in the dry matter) were the most likely cause of infertility problems in cows. However Austin et al. (1982) conclude that there was no evidence to indicate that herd fertility was suppressed by red clover silage.

Kale

The introduction of big bales for silage production provided the opportunity to conserve kale (Brassica oleracea) more effectively than had been previously achieved in clamps, despite its low dry matter concentration. Kale, which has high crude protein concentrations, can be grown as an early-sown catch crop or a late-sown main crop (Martyn et al. 1997). Other advantages of kale are its high DM yield relative to other brassica crops (Drew et al. 1974;) and digestibility (Young 1997a,b). The crude protein concentration of kale declines as the plant matures. Forage kale contains anti-metabolites, such as $S$ - methyl cysteine sulphoxide and glucosinolates, which break down in the rumen and lead to various toxicity symptoms in ruminants (Coxganser et al. 1994). However, the work of Fales et al. (1987) showed that ensiling forage brassicas can effectively reduce the potential toxicity of fresh brassica forages.

Marley et al. (2007) and Vipond et al. (1998) reported that relative to medium feed value grass silage ensiled kale increased live weight gain of finishing lambs. Furthermore, kale significantly improved nitrogen use efficiency in growing lambs compared to red clover, lucerne and ryegrass (Marley et al. 2007).

\section{Conclusions}

It is concluded that evidence from Ireland and UK show that in relation to grass silage digestibility is the most important factor influencing feed-value and consequently the performance of animals offered grass silage based diets. Each $10 \mathrm{~g} \mathrm{~kg}^{-1}$ increase in DOMD increases daily milk yield of lactating dairy cows by $0.33 \mathrm{~kg}$, daily carcass gain of beef cattle by $23.8 \mathrm{~g} \mathrm{head}^{-1}$, daily carcass gain of finishing lambs by $9.3 \mathrm{~g} \mathrm{head}^{-1}$, lamb birth weight by 52.3 $\mathrm{g}$, and ewe weight post lambing by $1.3 \mathrm{~kg}$. Harvest date is the main factor effecting silage digestibility. Each one week delay in harvest reduces digestibility by $3.3 \%$ units. To sustain animal performance due to delay of harvest by one week requires an additional $12.7 \mathrm{~kg}$ concentrate DM per ewe in late pregnancy, $0.20 \mathrm{~kg}$ concentrate DM 
T.W.J. Keady et al. (2013) 22: 70-92

daily per finishing lamb, $1.2 \mathrm{~kg}$ concentrate DM daily per finishing beef animal (depending on silage feed value and concentrate feed level), and $1.55 \mathrm{~kg}$ concentrate DM daily per lactating dairy cow. Solar radiation and swath density are the major factors effecting rate of water loss from herbage during wilting. Wilting results in increased silage DMI and reduced animal output per hectare. Potassium fertilizer impacts on herbage yield, but does not affect herbage ensilability or silage feed value. Chop length has no effect on silage DMI by dairy and beef cattle. However reducing chop length increases silage DMI by pregnant ewes and finishing lambs. Use of bacterial inoculants across a wide range of ensiling conditions and formic acid under difficult ensiling conditions increase animal performance.

In relation to alternative forages maize when produced using the CCPM system, can be produced at a similar cost as grazed grass (under Irish and UK conditions). Optimum stage to harvest maize is at approximately $300 \mathrm{~g} \mathrm{~kg}^{-1}$. Partially or totally replacing grass silage with maize silage in grass silage based diets increases the performance of finishing beef cattle, finishing lambs and pre-weaned lambs sucking their dams (which had been offered maize silage during pregnancy). Partially or totally replacing grass silage with whole crop wheat silage in grass silage based diets increases forage intake without any beneficial effect on animal performance. Advances in silage technology have opened up opportunity for ensiling high protein legume-based forages such as red clover, lucerne and kale. Offering red clover, lucerne and kale silages to lambs can improve live-weight gain relative to that with medium feed-value grass silage.

\section{References}

Apolant, S.M. \& Chestnutt, B.M.B. 1985. The effect of mechanical treatment of silage on intake and production of sheep. Animal Production 40: 287-296.

Austin, A.R., Aston, K., Drane, H.M. \& Saba, N. 1982. The fertility of heifers consuming red clover silage. Grass and Forage Science 37: 101-106.

Barrett, J.F., George, J.M. \& Lamond, D.R. 1965. Reproductive performance of Merino ewes grazing red clover (Trifolium pratense L.), improved pasture, or native pasture. Australian Journal of Agricultural Research 16: 189-200.

Beeckman, A., Vicca, J., Ranst, G. van, Janssens, G. P. J. \& Fievez, V. 2010. Monitoring of vitamin E status of dry, early and mid-late lactating organic dairy cows fed conserved roughages during the indoor period and factors influencing forage vitamin $E$ levels. Journal of Animal Physiology and Animal Nutrition 94: 736-746.

Benassayag, C., Perrot-Applanat, M. \& Ferre, F. 2002. Phytoestrogens as modulators of steroid action in target cells. Journal of Chromatography B. Analytical Technologies in the Biomedical and Life Sciences777: 233-248.

Black, H.J. \& Chestnutt, D.M.B. 1990. Influence of shearing regime and grass silage quality on the performance of pregnant ewes. Animal Production 51: 573-582.

Broderick, G. A. \& Albrecht, K. A. 1997. Ruminal in vitro degradation of protein in tannin-free and tannin-containing forage legume species. Crop Science 37: 1884-1891.

Butler, T.M. 1977. Effect of formic acid treatment, wilting and stage of growth on silage quality. An Foras Taluntais Animal Production Research report, Dublin, Ireland. p. 108-109.

Castle, M.E. \& Watson, J.N. 1971. Silage and milk production. A comparison between a diploid and a tetraploid ryegrass. Journal of the British Grassland Society 26: 256-270.

Chestnutt, D.M.B. 1989. Effect of silage quality on the performance of pregnant ewes. In: Sheep Production. Occasional Publication No. 17. Agricultural Research Institute of Northern Ireland. p. 3-14.

Coxganser, S.M., Jung, G.A., Pushkin R.T. \& Reid, R.L. 1994. Evaluation of brassicas in grazing systems for sheep. 2. Blood composition and nutrient status. Journal of Animal Science 72: 1832-1841.

Cushnahan, A., Gordon, F.J., Ferris, C.P., Chestnutt, D.M.B. \& Mayne, C.S. 1994. The use of sheep as a model to predict the relative intakes of silages by dairy cattle. Animal Production 59: 415-420.

Dewhurst R.J., Fisher W.J., Tweed J.K.S. \& Wilkins R.J. 2003a. Comparisons of grass and legume silages for milk production. 1. Production responses with different levels of concentrate. Journal of Dairy Science 86: 2598-2611.

Dewhurst R.J. 2012. Milk production from silage: comparison of grass, legume and maize silages and their mixtures. In: Kuoppala, K. et al. (eds.). Proceedings of the XVI International Silage Conference, Hameenlinna, Finland. p. 134-143

Dewhurst R.J., Evans R.T., Scollan N.D., Moorby J.M., Merry R.J. \& Wilkins R.J. 2003b. Comparison of grass and legume silages for milk production. 2. In vivo and in sacco evaluations of rumen function. Journal of Dairy Science 86: 2612-2621.

Doyle, C.J. \& Thomson, D.J. 1985. Potential of lucerne in British agriculture: an economic assessment. Grass and Forage Science 40: 57-68.

Drennan, M.J. \& Keane, M.G. 1987. Response to supplementary concentrates for finishing steers fed silage. Irish Journal of Agricultural research 26:115-127.

Drew K.R., Stephen R.C. \& Barry T.N. 1974. The composition and productive features of some forage crops for sheep. Proceedings of Agronomy Society of New Zealand. 4: 53-56. 
Fales, S.L., Gustine, D.L., Bosworth, S.C. \& Hoover, R.J. 1987. Concentrations of glusosinolates and S-methylene sulphoxide in ensiled rape (Brassica napus L.). Journal of Dairy Science 70: 2402-2405.

Fitzgerald, J.J. 1986. Effect of formic acid treatment or wilting and concentrate supplementation on silage intake and performance of store lambs. Irish Journal of Agricultural Research 25: 327-346.

Fitzgerald, J.J. 1987. Finishing store lambs on silage-based diets. 4. Effects of stage of grass growth when ensiled and barley supplementation on silage intake and lamb performance. Irish Journal of Agricultural Research 26: 139-151.

Fitzgerald, J.J. 1996. Grass silage as a basic feed for store lambs. 3. Effect of barley supplementation of silages varying in chop length on silage intake and lamb performance. Grass and Forage Science 51: 389-403.

Flynn, A.V. 1981. The relative importance of different factors in determining the beef production potential of silage. PhD Thesis, National University of Ireland, Dublin, Ireland.

Fraser M.D., Fychan R. \& Jones R. 2000. Voluntary intake, digestibility and nitrogen utilisation by sheep fed ensiled forage legumes. Grass and Forage Science 55: 271-279.

Fraser, M. D., Davies, D. A., Wright, I. A., Vale, J. E., Nute, G. R., Hallett, K. G. \& Richardson, R. I. 2007. Effect on upland beef production of incorporating winter feeding of red clover silage or summer grazing of Molinia-dominated semi-natural pastures. Grass \& Forage Science 62: 284-300.

Fychan, A. R., Jones, R. \&Roberts, J. E. 2002a. The effect of wilting on the ensiling potential of red clover and lucerne. In: Gechie, L. \& M.Thomas, C. (eds.). Proceedings XIII International Silage Conference, 11-13 September 2002, Auchincruive, Scotland, p.102-103.

Fychan, A. R., Roberts, J. E. \& Theobald, V. J. 2002b. Yield and silage quality of red clover and lucerne stands. In: Gechie, L. \& M.Thomas, C. (eds.). Proceedings XIII International Silage Conference, 11-13 September 2002, Auchincruive, Scotland. p. 88-89.

Fychan, A. R., Fraser, M. D. \& Jones, R. (2002c). Effect of ensiling method on the quality of red clover and lucerne silage. In: Gechie, L. \& M.Thomas, C. (eds.). Proceedings XIII International Silage Conference, 11-13 September 2002, Auchincruive, Scotland. p.104-105. Gordon, F.J. 1980a. The effect of interval between harvesting and wilting on silage for milk production. Animal Production 31: 35-41.

Gordon, F.J. 1980b. The effect of silage type on the performance of lactating cows and the response to high levels of protein in the supplement. Animal Production, 30: 29-37.

Gordon, F.J. 1982. The effects of degree of chopping grass for silage and method of concentrate allocation on the performance of dairy cows. Grass and Forage Science 37: 59-66.

Gordon, F.J. 1989. An evaluation through lactating cattle of a bacterial inoculant as an additive for grass silage. Grass and Forage Science 44: 169-179.

Gordon, F.J., Dawson, L.E.R., Ferris, C.P., Steen, R.W.J. \& Kilpatrick, D.J. 1999. The influence of wilting and forage additive type on the energy utilisation of grass silage by growing cattle. Animal Feed Science and Technology 79: 15-27.

Han, K. J., Collins, M., Vanzant, E. S. \& Dougherty, C. T. 2006. Characteristics of baled silage made from first and second harvests of wilted and severely wilted forages. Grass and Forage Science 61: 22-31.

Heron, S.J., Henderson, A.R. \& Cunningham, M. 1987. The effects of inoculation with enterobacteria and progeolytic clostridia on ensiling sterile and non-sterile ryegrass. Proceedings of the VIII Silage Conference, Institute for Grassland and Animal Production, Hurley. p. 5-6.

Humphreys, J. \& O'Kiely, P. 2007. Effects of two mixtures of perennial ryegrass cultivars with contrasting heading dates, and differing in spring-grazing frequency and silage harvest date, on characteristics of silage from first-cut swards. Grass and Forage Science 62: 389-404.

Jaakkola, S., Toivonen, V. \& Huhtanen, P. 1999. Effects of nitrogenfertilization of grass on fermentation in untreated and formic acid treated silage. Proceedings of the XII International Silage Conference, Uppsala, Sweden. p.164-165.

Jones, B.A., Hatfield, R.D. \& Muck, R.E. 1995a. Characterisation of proteolysis in alfalfa and red clover. Crop Science 35: 537-541.

Jones, B.A., Muck, R.E. \& Hatfield, R.D. 1995b. Red clover extracts inhibit legume proteolysis. Journal of the Science of Food and Agriculture 67: 329-333.

Kallela, K., Heinonen, K. \& Saloniemi, H. 1984. Plant oestrogens; the cause of decreased fertility in cows. A case report. Nordisk Veterinaer Medicin 36: 124-129.

Kalu, B.A. \& Fick, G.W. 1981. Quantifying morphological development of alfalfa for studies of herbage quality. Crop Science 21 : 267-271.

Keady, T.W.J. 1991. Studies of the mode of action of a bacterial inoculant as a silage additive and an evaluation of its efficacy. PhD Thesis. The Queens University, Belfast, Northern Ireland.

Keady, T.W.J. 1996. A review of the effects of molasses treatment of unwilted grass at ensiling on silage fermentation, digestibility and intake, and on animal performance. Irish Journal of Agricultural and Food Research 35: 141-150.

Keady T.W.J. 1998. The production of high feed value silage and the choice of compound feed type to maximise animal performance. In: Lyons, T.P. \& Jacques, K.A. (eds.). Biotechnology in the Feed Industry. Proceedings of Alltech's $14^{\text {th }}$ Annual Symposium.. p. $157-180$

Keady, T.W.J. 2000. Beyond the science: what the farmer looks for in the production of silage. In: Lyons, T.P. \& Jacques, K.A. (eds.). Biotechnology in the Feed Industry. Proceedings of Alltech's 16 $6^{\text {th }}$ Annual symposium. p. 439-452.

Keady, T.W.J. 2005. Ensiled maize and whole crop wheat forages for beef and dairy cattle: effects on animal performance. In: Park, R.S. \& Stronge, M.D. (eds.). Silage production and utilizationtechnology. Proceedings of the XIVth International Silage Conference, Belfast, Northern Ireland. p. 65-82. 
T.W.J. Keady et al. (2013) 22: 70-92

Keady T.W.J., Fitzgerald J.J., Murphy J.J. \& Byrne N. 2002. An evaluation of herbage dry matter at ensiling and concentrate type on food intake and performance of lactating dairy cattle. In: Proceedings of the Agricultural Research Forum 2012, Ireland. p. 61.

Keady, T.W.J., Gordon A.W. \& Moss B.W. 2013. Effects of replacing grass silage with mazie silages differing in inclusion level and maturity on the performance, meat quality and concentrate sparing effect of beef cattle. Animal (in press).

Keady, T.W.J. \&and Hanrahan J.P. 2008. The effects of grass silage harvest systems, concentrate feed level and maize silage maturity and soyabean supplementation on ewe and subsequent lamb performance. Proceedings of the British Society of Animal Science. p. 125

Keady, T.W.J. \& Hanrahan, J.P. 2009a. The effects of maturity of maize at harvest and soyabean supplementation, grass silage feed value and concentrate feed level on ewe and subsequent lamb performance. In: Proceedings of the XVth International Silage Conference, Madison, Wisconsin. p.133-134.

Keady, T.W.J. \& Hanrahan, J.P. 2009b. Effects of shearing at housing, grass silage feed value and extended grazing herbage allowance on ewe and subsequent lamb performance. Animal 3: 143-151.

Keady, T.W.J. \& Hanrahan, J.P. 2009c. The effects of allowance and frequency of allocation of deferred herbage and grass silage feed value, when offered to ewes in mid-gestation on ewe and lamb performance and subsequent herbage yield. Animal 3: 879-890.

Keady, T.W.J. \& Hanrahan, J.P. 2009d. The effects of supplementation of maize silage diets during pregnancy on ewe and subsequent lamb performance. In: Proceedings of the British Society of Animal Science. p. 51

Keady, T.W.J. \& Hanrahan, J.P. 2010. An evaluation of the effect of grass silage and concentrate feed level on ewe and subsequent progeny performance and on potential concentrate sparing effect. In: Proceeding of the British Society of Animal Science. p. 38.

Keady, T.W.J. \& Hanrahan, J.P. 2012a. Effects of plane of nutrition during the rearing phase and pregnancy on the performance of ewes lambing at 2 years of age. In: Proceedings of the British Society of Animal Science. p. 161.

Keady, T.W.J. \& Hanrahan, J.P. 2012b. The effects of forage type and feed value, concentrate feed level and protein concentration and shearing on lamb performance. In: Kuoppala, K. et al. (eds.)Proceedings of the XVIth International Silage Conference, Hameenlinna, Finland. p. $168-169$.

Keady, T.W.J. \& Hanrahan, J.P. 2013. Effects of maturity of maize at harvest, grass silage feed value and concentrate feed level on performance of, and potential concentrate sparing effect when offered to finishing lambs. Animal. (in press).

Keady, T.W.J., Hanrahan, J.P. \& Flanagan, S. 2007. Effects of extended grazing during mid, late or throughout pregnancy, and winter shearing of housed ewes, on ewe and lamb performance. Irish Journal of Agricultural and Food Research 46: 169-180.

Keady, T.W.J. \& Kilpatrick, D.J. 2006. The effect of forage: concentrate ratio on the performance of bulls slaughtered at a range of liveweights. In: Proceedings of the British Society of Animal Science. p. 50.

Keady, T.W.J., Kilpatrick, D.J., Mayne, C.S. \& Gordon, F.J. 2008a. Effects of replacing grass silage with maize silages, differing in maturity, on performance and potential concentrate sparing effect of dairy cows offered two feed value grass silages. Livestock Science 119: 1-11.

Keady, T.W.J., Lively, F.O., Kilpatrick, D.J. \& Moss, B.W. 2007. Effects of replacing grass silage with either maize or whole-crop wheat silages on the performance and meat quality of beef cattle offered two levels of concentrates. Animal 1: 613-623.

Keady, T.W.J., Lively, F.O., Kilpatrick, D.J. \& Moss, B.W. 2008b. The effects of grain treatment, grain feed level and grass silage feed value on the performance of and meat from, finishing beef cattle. Animal 2: 149-159.

Keady, T.W.J., Mayne, C.S. \& Fitzpatrick, D.A. 2000. Prediction of silage feeding value from the analysis of the herbage at ensiling and effects of nitrogen fertilizer, date of harvest and additive treatment on grass silage composition. Journal of Agricultural Science, Cambridge 134: 353-368.

Keady, T.W.J., Mayne, C.S. \& Kilpatrick, D.J. 2001. Production of silage dry matter digestibility from digestible organic matter digestibility. In: Proceedings of the British Society of Animal Science. p. 93.

Keady, T.W.J., Mayne, C.S. \& Kilpatrick, D.J. 2003. The effect of maturity of maize silage at harvest on the performance of lactating dairy cows offered three contrasting grass silages. In: Proceedings of the British Society of Animal Science. p. 126.

Keady, T.W.J., Mayne, C.S., McConaghy, D.A. \& Marsden, M. 1999. The effects of energy source and level of digestible undegradable protein in concentrates on silage intake and performance of lactating dairy cows offered a range of grass silages. Animal Science 68: 763-777.

Keady, T.W.J. \& Murphy, J.J. 1993. The effect of ensiling on dry matter intake and animal performance. Irish Grassland and Animal Production Association Journal 27: 19-28.

Keady, T.W.J. \& Murphy, J.J. 1998. The effects of ensiling and supplementation with sucrose and fishmeal on forage intake and milk production of lactating dairy cows. Animal Science 66: 9-20.

Keady, T.W.J., Murphy, J.J. \& Harrington, D. 1995. The effects of ensiling on dry-matter intake and milk production by lactating dairy cattle given forage as the sole feed. Grass and Forage Science 51: 131-141.

Keady, T.W.J. \& O'Kiely, P. 1996. An evaluation of the effects of rate of nitrogen fertilization of grassland on silage fermentation, in-silo losses, effluent production and aerobic stability. Grass and Forage Science 51: 350-362.

Keady T.W.J. \& O'Kiely P. 1998. An evaluation of potassium and nitrogen fertilization of grassland, and date of harvest, on fermentation, effluent production, dry-matter recovery and predicted feeding value of silage. Grass and Forage Science 53: 326-337.

Keady, T.W.J. \& Steen, R.W.J. 1994. Effects of treating low dry matter grass with a bacterial inoculant on the intake and performance of beef cattle, and studies on its mode of action. Grass and Forage Science 49: 438-336.

Keady, T.W.J. \& Steen, R.W.J. 1995. The effects of treating low dry matter, low digestibility grass with a bacterial inoculant on the intake and performance of beef cattle, and studies on its mode of action. Grass and Forage Science 50: 217-226. 
Keady, T.W.J., Steen ,R.W.J., Kilpatrick D.J. \& Mayne C.S. 1994. Effects of inoculant treatment on silage fermentation, digestibility and intake by growing cattle. Grass and Forage Science 49: 284-294.

Keating, T. \& O'Kiely, P. 2000. Comparison of old permanent grassland, Lolium perenne and Lolium multiflorum swards grown for silage 1 Effects on beef production per hectare. Irish Journal of Agricultural and Food Research 39: 1-24.

Long, F.N.J., Kennedy, S.J. \& Gracey H.I. 1991. Effect of fertilizer nitrogen rate and timing on herbage production and nitrogen use efficiency for first cut silage. Grass and Forage Science 46: 231-237.

Marley, C.L., Fychan, F., Fraser, M.D., Winters, A. \& Jones, R. 2003. Effect of sowing ratio and stage of maturity at harvest on yield, persistency and chemical composition of fresh and ensiled red clover/lucerne bi-crops. Grass and Forage Science 58: 397-406.

Marley, C.L., Fychan, R., Fraser, M.D., Sanderson, R. \& Jones, R. 2007. Effects of feeding different ensiled forages on the productivity and nutrient-use efficiency of finishing lambs. Grass and Forage Science 62: 1-12.

Martyn, T.M., Young, N.E. \& Balsdon, S.L. 1997. Comparison of the herbage yields of three kale (Brassica oleracea L.) cultivars. Annals of Applied Biology, 130: 44-45.

McDonald, P., Henderson, A.R. \& Heron J.J.E. 1991. The biochemistry of silage. Buckinghamshire, U.K: Chalcombe Publications. 340 p. McKersie, B.D. 1985. Effect of pH on proteolysis in ensiled legume forage. Agronomy Journal 77: 81-86.

Muck, R.E. \& Walgenbach, R.P. 1985. Variations in alfalfa buffering capacity. In: Proceedings of the American Society of Agricultural Engineers, Chicago, US. Paper 85: 1535.

Ohlsson C. \& Wedin W.F. 1989. Phenological staging schemes for predicting red clover quality. Crop Science 29: 416-420.

O'Kiely, P. 1994. Effects of adding a bacterial inoculant to grass ensiled at different dry matter concentrations and offered to beef cattle. Animal Science 58: 456 (abstract).

O'Kiely, P. 2011. Intake, growth and feed efficiency of finishing beef cattle offered diets based on triticale, maize or grass silages, or concentrates. Irish Journal of Agricultural and Food Research 50: 189-208.

O'Kiely P., Flynn A.V. \& Wilson R. 1987. New concepts in silage making. Irish Grassland and Animal Production Association Journal 21: 38-50.

Papadopoulos, Y.A. \& McKersie, B.D. 1983. A comparison of protein degradation during wilting and ensiling of six forage species. Canadian Journal of Plant Science 63: 903-912.

Patterson, D.C., Yan, T. \& Gordon, F.J. 1996. The effects of wilting of grass prior to ensiling on the response to bacterial inoculation. 2. Intake and performance by dairy cattle over three harvests. Animal Science 62: 419-429.

Patterson, D.C., Yan, T., Gordon, F.J. \& Kilpatrick, D.J. 1998. Effects of bacterial inoculation of unwilted and wilted grass silages. 2. Intake, performance and eating behaviour by dairy cattle. Journal of Agricultural Science 131: 113-119.

Pitt, R.E. 1990. Silage and Hay Preservation Report. NRAES-5. Northeast Region Agricultural Engineering Service, Ithaca, New York, USA. p. 1-53.

Pocknee, B.R. \& Campling, R.C. 1981. Voluntary intake and digestibility of lucerne silages by steers. Grass and Forage Science 36 : 141-142.

Raguse, C.A. \& Smith, D. 1966.Some non-structural carbohydrates in forage legume herbage. Journal of Agricultural and Food Chemistry, 14: 423-426.

Randby, A.T., Weisbjerg, M.R., Nogaard, P. \& Heringstad, B. 2012. Feed intake and milk yield response during early lactation of cows offered grass silages harvested at early maturity stages. In: Kuoppala, K. et al. (eds.). Proceedings of the XVI International Silage Conference, Hämeenlinna, Finland. p 148-149.

Robinson, J.J. (1983). Nutrition of the pregnant ewe. In: Haresign, W. (ed.). Sheep Production. London: Butterworth . p. 111-132.

Rohr, K. \& Thomas, C. 1984. Intake digestibility and animal performance. In: Zimmer, E. \& Wilkins, R.J. (eds.). Efficiency of silage systems: a comparison between unwilted and wilted silages. Landbanforschung Volkenrode, Sonderheft 69. p. 64-70.

Sarelli, L., Tuori, M., Saastamoinen, I., Syrjala-Qvist, L. \& Saloniemi, H. 2003. Phyto-oestrogen content of birdsfoot trefoil and red clover effects of growth stage and ensiling method. Acta Agriculturae Scandinavica Section A - Animal Science 53: 58-63.

Speijers M.H.M., Fraser M.D., Theobald V.J \& Haresign W. 2005a. Effects of ensiled forage legumes on performance of store finishing lambs. Animal Feed Science and Technology 120: 203-216.

Speijers M.H.M., Fraser M.D., Haresign W., Theobald V.J. \& Moorby J.M. 2005b. Effects of ensiled forage legumes on performance of twin-bearing ewes and their progeny. Animal Science 81: 271-282.

Steen, R.W.J. 1984a. The effects of wilting and mechanical treatment of grass prior to ensiling on the performance of beef cattle and beef output per hectare. In: Fifty-seventh Annual Report of the Agricultural Research Institute of Northern Ireland. p. 21-32.

Steen, R.W.J. 1984b. A comparison of two-cut and three-cut systems of silage making for beef cattle using two cultivars of perennial ryegrass. Animal Production 38: 171-179.

Steen, R.W.J. 1992. The performance of beef cattle given silages made form perennial ryegrass of different maturity groups, cut on different dates. Grass and Forage Science 47: 239-248.

Steen, R.W.J. \& Gordon, F.J. 1980. The effect of type of silage and level of concentrate supplementation offered during early lactation on total lactation response of January/February calving cows. Animal Production 30: 341-354.

Steen, R.W.J. \& Mcllmoyle, W.A. 1982a. Effect of animal size on the response in the performance of beef cattle to an improvement in silage quality. Animal Production 34: 301- 308.

Steen, R.W.J. \& Mcllmoyle, W.A. 1982b. The effect of frequency of harvesting grass for silage and level of concentrate supplementation on the intake and performance of beef cattle. Animal Production 35: 245-252. 
Steen, R.W.J., Kilpatrick, D.J. \& Porter, M.G. 2002. Effects of the proportion of high or medium digestibility grass silage and concentrates in the diet of beef cattle on ADG, carcass composition and fatty acid composition of muscle. Grass and Forage Science 57: 279-291.

Thomas, C., Daley, S.R., Aston, K. \& Hughes, P.M. 1981. Milk production from silage. 2. The invluence of the digestibility of silage made from the primary growth of perennial tyegrass. Animal Production 33: 7-13.

Thomson, D.J. 1975. The effect of feeding red clover conserved by drying or ensiling on reproduction in the ewe. Grass and Forage Science 30: 149-152.

Urpi-Sarda, M., Morand, C., Besson, C., Kraft, G., Viala, D., Scalbert, A., Besle, J. M. \& Manach, C. 2008. Tissue distribution of isoflavones in ewes after consumption of red clover silage. Archives of Biochemistry and Biophysics 476: 205-210.

Vipond J.E., Duncan A.J., Turner D., Goddyn L. \& Horgan G.W. 1998. Effects of feeding ensiled kale (Brassica oleracea) on the performance of finishing lambs. Grass and Forage Science 53: 346-352.

Walsh, K., O'Kiely, P., Moloney, A.P. \& Boland, T.M. 2008. Intake, performance and carcass characteristics of beef cattle offered diets based on whole crop wheat or forage maize relative to grass silage or ad-libitum concentrations. Livestock Science 116: 223-236.

Wilkins, R.J. 1984. Review of former data. In: Zimmer, E. \& Wilkins, R.J. (eds.). Efficiency of silage systems: a comparison between unwilted and wilted silages . Landbanforschung Volkenrode, Sonderheft 69. p. 5-12

Wilkinson, J.M. 1978. The ensiling of forage maize: effects on composition and nutritive value. In: Bunting E.S., Pain B.E., Phipps R.H., Wilkinson J.M. \& Gunn R.E. (eds). Forage Maize, London, UK: Agricultural Research Council. p 346.

Wilson, R.K. \& Flynn, A.V. 1979. Effects of fertiliser-N, wilting and delayed sealing on the chemical composition of grass silages made in laboratory silos. Irish Journal of Agricultural Research 18:13-23.

Wright D.A. 1997. The influence of different factors on the drying rate of grass silage and development of prediction models. PhD Thesis, The Queens's University, Belfast.

Wright, D.A., Gordon, F.J., Steen, R.W.J. \& Patterson, D.C. 2000. Factors influencing the response in intake of silage and animal performance after wilting of grass before ensiling: a review. Grass and Forage Science 55: 1-13.

Yan, T., Patterson, D.C., Gordon, F.J. \& Porter, M.E. 1996. The effects of wilting grass prior to ensiling on the response to bacterial inoculation. I. Silage fermentation and nutrient utilisation over three harvests. Animal Science 62: 405-417.

Young N.E. 1997a. Growing and conserving kale/barley as a bi-crop. In: Quality Forage for Ruminants, Proceedings of a RAC, BGS, BSAS and MGA conference, Royal Agricultural College, Cirencester, 5 March 1997, poster paper 1. Reading, UK: British Grassland Society.

Young N.E., Patey R., Jones R. \& Fychan 1997b. Kale for conservation. Technical Advisory Report No. 1, Institute of Grassland and environmental Research, Aberystwyth. Aberystwyth, UK: Institute of Grassland and Environmental Research. 